\title{
Grafitos históricos en la casa morisca de calle San Martín, 16 (Granada)
}

\section{Ancient times graffitti in the morisco house at $n$. 16, San Martin street (Granada)}

\author{
José Ignacio Barrera Maturana*
}

\begin{abstract}
RESU MEN
Con este artículo damos a conocer un interesante conjunto de grafitos históricos descubiertos en una casa morisca de Granada. Su importancia no sólo se debe a la gran variedad temática que ofrecen, sino que constituyen las primeras manifestaciones glipto gráficas, procedentes de una antigua casa morisca, que son objeto de estudio en nuestra ciudad.
\end{abstract}

Palabras clave: Grafitos, casa morisca, diseños geométricos, figuras humanas, motivos arquitectónicos, Granada.

Desgraciadamente muy a menudo se nos informa en los medios de comunicación, del derribo intencionado o desplome por abandono de antiguas casas del Albayzín, fruto de una imparable especulación inmobiliaria que se cierne sobre el barrio granadino. La tónica generalizada hasta ahora, ha sido que tras la irreparable desaparición del edificio, la actuación científica se ha reducido a un sondeo arqueológico en el solar.

Unas veces, se consigue que solamente se mantengan en pie las fachadas de estos edificios, obedeciendo a normativas, que por otro lado, ignoran lo que esos viejos muros internos pudieran contener. También hemos podido

\begin{abstract}
W ith this article we show an interesting group of historic graffiti discovered in a morisco house from Granada. The importance is due that not only great variety thematic that offer but these constitute the first gliptographics manifestations from an old morisco house that are aim of studying of our city.
\end{abstract}

Key words: Graffiti, morisco house, geometric design, human figures, architectural patterns, Granada.

comprobar como durante la rehabilitación de algunas de estas antiguas viviendas, se lleva a cabo un agresivo repicado de los distintos revestimientos de los muros, destruyendo de este modo, los grafitos históricos que pudieran existir. La demolición de edificios, sin que se efectúe previamente un detenido estudio de sus muros, ha supuesto la desaparición, con to da seguridad, de un sin fin de manifestaciones gliptográficas de todas las épocas, que desgraciadamente no hemos podido documentar. Unas manifestaciones populares que ofrecen información directa y de primera mano de un momento histórico concreto, así como de las personas que las ejecutaron ${ }^{1}$.

* Arqueólogo

1 Valgan las palabras de Elvira González Gozalo: "En Arqueología no sólo hay que mirar al suelo 0 al subsuelo, sino a las paredes, tan valiosos documentos llenos de datos de nuestra historia", ("Arqueología de pared", en edición digital del Diario de Mallorca, Sábado 09-06-2007). 
Por tanto, sirva este trabajo de llamada ante la necesidad de establecer una estrecha colaboración, inexistente hasta ahora en nuestra tierra, entre arquitectos, arqueólogos y los que nos dedicamos al estudio de estos motivos, con el objeto de proteger, estudiar y difundir un patrimonio histórico y cultural digno de salvaguardar.

A principios del 2005 emprendimos el estudio de una serie de grafitos históricos aparecidos durante los trabajos arqueológicos y de rehabilitación, que el Laboratorio de Arqueología y Arquitectura de la Ciudad (LAAC), de la Escuela de Estudios Árabes de Granada (CSIC), realizaba en la casa morisca de la calle San Buenaventura número 2 y en la medianera, conocida como Casa de Yanguas, del barrio del Albayzín (Granada). Con posterioridad a esa fecha, nos fue comunicada la aparición de otros grafitos en una segunda casa, cercana a la anterior y situada esta vez en la calle San Martín número 16. Estos motivos serían también objeto de nuestro estudio, gracias al interés mostrado por el propietario de la vivienda, deseoso de conservarlos e integrarlos, como un elemento histórico más de la casa?

Sucesivas visitas a los emplazamientos nos permitieron documentar mediante dibujos y fotografías, los motivos, que tras los trabajos de limpieza de paramentos, fueron saliendo a la luz.

Una vez localizados los grafitos procedimos a delimitar el espacio que ocupaban en los muros, limpiar los enlucidos sobre los que se habían trazado, tomar las medidas necesarias de ubicación y confeccionar fichas de catalogación (Fig.1). A continuación, utilizamos una luz artificial rasante para detectar mejor el trazo de los motivos, llevando a cabo el calco directo de los mismos.

A unque estamos desarrollando actualmente trabajos más detallados de cada grafito 0 de grupos de ellos con temática similar, que se publicarán próximamente, recogemos en estas breves líneas una primera aproximación al estudio de los numerosos motivos descubiertos en la casa de C/ San Martín, 16, destacando la temática tan variada que muestran y ofreciendo unos primeros resultados cronológicos.

En relación a los grafitos descubiertos en la casa de C/ San Buenaventura, 2, decir tan solo, que dado que fueron ejecutados en un espacio temporal histórico no contemplado por esta revista (s. XVIII), serán presentados en otro lugar más adecuado.

A partir de aquí, utilizaremos tanto en el texto como en los pies de figuras y láminas, las siglas C/SM, cuando hagamos alusión a la casa de C/ San Martín, 16.

\section{LOCALIZACIÓN DE LOS GRAFITOS EN LA CASA}

\section{Contexto Histórico}

D urante las obras de rehabilitación (aún en proceso) de la casa albaicinera, sita en la zona denominada en época medieval "arrabal de Albaida" 3 (Fig.2), quedaron al descubier to en las crujías norte y este del edificio, las plantas baja, primera y galerías superiores sobre pórticos adintelados, de una modesta casa morisca.

Se trata de una de tantas viviendas que en el siglo XVI se construyeron en esta zona de

\footnotetext{
2 A gradezco a Antonio 0 rihuela Uzal (Escuela de Estudios Árabes de Granada - C SIC), la oportunidad que me ha brindado de poder estudiar estos motivos, así como a Antonio Díaz Avilés y a Santiago Cremades Picó, por todas las facilidades e interés mostrado.

3 En palabras de Luis Seco de Lucena, "El Barrio de la Albaida lindaba por el Norte y E. con la Cerca de Don Gonzalo; por el O. con el Albayzín y por el S. con la Cuesta del Chapiz, comprendiendo la placeta del Peso de la Harina, donde se alzaban un suntuoso palacio y la rábita Alah-deb, las Cuestas de los Chinos y Montes Claros, las calles de San Martín y de San Luis, la placeta y los vericuetos de la Cruz de la Rauda y la Cruz de Piedra y los cármenes de Aben-Mardanix. En el nombre de la placeta Rabo de Albaida (actualmente Placeta de A lbaida), que comunica con la calle del Salvador, se ha perpetuado, aunque corregido, el recuerdo etimológico de este entonces popular arrabal" (SECO DE LUCEN A, 1910: 37-38).
} 
la ciudad, aunque en algunas ocasiones se ha podido comprobar que son el resultado de las reformas 0 ampliaciones efectuadas sobre antiguas casas nazaríes, como por ejemplo la casa de C/ San Buenaventura, 2.

La edificación de estas viviendas por los moriscos granadinos, habría que entenderlo como el resultado de la implantación de un programa de segregación social y reubicación de la población musulmana granadina en dos morerías. Una se situaba en el entorno de la Mezquita Mayor,Zacatín, Plazas de Bibarrambla y de Bibalmazda, y la otra en el Albayzín.

Este programa fue pactado en 1495, entre el alfaquí M ohamed el Pequeñí, en representación de los mudéjares de Granada, y don Hernando de Zafra.

Se dispuso que todos aquellos mudéjares que no fueran vecinos de Granada, regresaran a su lugar de origen y vendieran sus casas a los nuevos poblado res cristianos. Así mismo, los vecinos de poblaciones de la vega que tuvieran casas en la ciudad, deberían también de venderlas a los cristianos. Por último, se comprarían en el Albayzín más de cuatrocientas casas que estaban vacías para vendérselas al mismo precio a los mudéjares que vivieran en otras zonas de la ciudad, vendiendo estos, a su vez, sus casas a cristianos. En definitiva, el resto de la Medina y otras zonas de la ciudad, como por ejemplo la Judería y el barrio de Axares, quedaría en manos de los nuevos pobladores.

En palabras de Rafael López Guzmán, "Luego, no estamos a principios del siglo XVI inmersos en un importante proceso constructivo ex-novo, sino en la adaptación y continuación del módulo habitacional nazarí.Viviendas recuperadas, aunque con carácter palaciego, como las denominadas casas árabes de Z afra y Horno del Oro nos sirven de ejemplos" (LÓ PEZ, 2007:19, 21 Y 27).

Por tanto, este traslado de la población musulmana granadina de la ciudad a la morería del Albayzín, supuso la ocupación de esas casas vacías que se reseñan en el documento, pero también surgirán a lo largo del siglo XVI nuevas edificaciones. U nas, resultado de las reformas 0 ampliaciones efectuadas so bre las antiguas casas nazaríes, y otras de nueva construcción.

Pero muchas de estas casas moriscas, aunque mantuvieron las características básicas de la arquitectura residencial nazarí de los siglos X III$\mathrm{XV}$, en distintos momentos del siglo XVI, debieron de realizar importantes modificaciones, en base a normas dictadas por los cristianos. Por ejemplo, la eliminación de saledizos y ajimeces, que dificultaban el paso por las angostas calles, o el sistema de acceso en recodo desde la calle al interior de la vivienda, ya que se obligó a los moriscos a tener abiertas las puertas de sus casas, con objeto de poder observar si seguían manteniendo ritos y costumbres islámicas en su interior (O RIHUELA, 2007: 220).

La influencia castellana se deja sentir, según algunos autores, con la utilización del pie derecho en las galerías (CAÑ AVATE, 2006: 271-273, 333-334). Así mismo, la iconografía tradicional cristiana aparece reflejada en el tallado de las maderas de las galerías, con elementos decorativos de estilo gótico al principio y renacentistas después, que se combinarán con los de tradición islámica, como los mocárabes (O RIHUELA, 2008).

Tras la rebelión de 1568, se produce la expulsión de los moriscos granadinos, que culminará con la expulsión general de 1610 .

Los moriscos del Albayzín fueron sacados de mala manera y repartidos por Andalucía y Castilla. Supuso el abandono de sus hogares y haciendas. Esta marcha, con el tiempo, daría lugar a una reconversión del paisaje urbano del barrio, que se ruraliza. Al disminuir la densidad de su población, las viviendas serán reocupadas y ampliadas y la vegetación ocupará grandes espacios.

llustran estos hechos, las siguiente palabras de Luis del Mármol Carvajal en el Libro VI, Capítulo XXVII:

"Como se sacaron los moriscos del Albaicin de Granada, y los metieron la tierra adentro" 
"Fue miserable espectáculo ver tantos hombres de todas edades, las cabezas bajas, las manos cruzadas y los rostros bañados de lágrimas, con semblante doloroso y triste viendo que dejaban sus regaladas casas, sus familias, su patria, su naturaleza, sus haciendas y tanto bien como tenían, y aún no sabían cierto lo que se haría de sus cabezas".

“H echo esto, comenzó á sentirse mas seguridad en la ciudad, aunque quedó grandísima lástima á los que, habiendo visto la prosperidad, la policía y el regalo de las casas, cármenes y huertas, donde los moriscos tenían todas sus recreaciones y pasatiempos, y desde á pocos días lo vieron todo asolado y destruido, y tan mal parado que parecía bien estar sujeta aquella felicísima ciudad á tal destrucción" (MARMO L, 1600:183-184).

\section{Los grafitos}

Los grafitos objeto de nuestro estudio, posiblemente fueron trazados en un momento de abandono o reocupación de la casa morisca.

Se localizaron en el interior de la estancia situada en la primera planta de la crujía este del edificio. Se accede a ella por una galería superior y a través de una puerta que conserva aún en ambas jambas sus correspondientes tacas. A parecen incisos sobre el antiguo enlucido de yeso que cubre los muros de ladrillo que se extienden a derecha e izquierda de la puerta (Paneles 1-C/SM y 2-C/SM).

0 tro grupo de motivos, también incisos sobre yeso, se descubrieron en el muro de carga, levantado mediante tapias de tierra, que cerraba esta crujía por el este (Panel 3-C/ SM).

Por último, junto al pie derecho de la galería superior de acceso a esta misma sala, se localizó un nuevo motivo inciso (Panel 4-C/SM).

En la primera planta de la crujía norte, los grafitos, pintados e incisos sobre yeso, se localizaron en el muro exterior, también de ladrillo, de la sala principal. Exactamente se distribuyen a lo largo de la galería superior de acceso a la sala (Panel 5-C/SM). Bajo este enlucido de yeso, se detectó la presencia de una alacena, que se abría hacia el interior de la sala.

Los elementos que contienen los distintos paneles referidos, quedan resumidos de la siguiente manera:

Panel 1-C/SM (Fig.3): Podemos ver incisos en el yeso, una gran figura femenina, algunos "elementos de cuenta" y círculos concéntricos realizados a compás. Sobre uno de los pies del personaje se aprecia una posible inscripción, al parecer en caracteres árabes.

Panel 2-C/SM (Fig.4):Toda la superficie de este panel aparece cubierta, principalmente, por un gran número de "elementos de cuenta". A proximadamente a mitad del muro, se puede ver una roseta de gran tamaño y una figura que recuerda a un corazón coronado por una cruz patriarcal. Todos estos motivos aparecen igualmente incisos.

Panel 3-C/SM (Fig.5): También mediante incisión, observamos el trazado de un rostro de aspecto grotesco y dos personajes con faldas cuadriculadas. Uno de ellos mantiene los brazos en cruz, ligeramente elevados. Por encima de estos personajes, una figura geométrica trazada a compás y algunos "elementos de cuenta".

Panel 4-C/SM (Fig.6): Incisa en el enlucido se traza una torre con cubierta a dos aguas, cuyo interior queda dividido en tres o cuatro plantas, a las que se accede con escaleras dispuestas en zig-zag. En el interior de las plantas se dibujan cinco piezas de artillería, cuatro que apuntan hacia la derecha y una hacia la izquierda. Una de ellas dispara un proyectil contra una estrella de seis puntas. En la planta tercera aparece un arco coronado por una pequeña cruz y en la segunda, algunos números.

Panel 5-C/SM (Fig.7): Constituye el panel más grande y numeroso en lo que a motivos se refiere. Se detecta el uso de dos técnicas en la ejecución de los grafitos: incisos y dibujados a 
carboncillo. Entre los primeros, tenemos motivos realizados a compás, que forman círculos concéntricos y complejas formas geométricas, donde se mezclan estrellas de seis puntas, rosetas hexapétalas y arquitos entrecruzados. Vemos estrellas aisladas de ocho y seis puntas, "elementos de cuenta", cruces contorneadas insertas en círculos, un posible monograma de "Ave Maria", una inscripción árabe, un antropomorfo, un reticulado, algunos números y letras en recuadros y un enorme castillo. D ibujados a carboncillo, tenemos algunos "elementos de cuenta", un personaje con sombrero y un barco.

\section{TEMÁTICA DE LOS GRAFITOS}

Hemos agrupado los distintos grafitos, en base a la temática que ofrecen. Así pues, las catego rías creadas han sido las siguientes: barcos, figuras humanas,"elementos de cuenta", motivos simbólicos y geométricos (posible monograma de "Ave María", corazón, cruces, estrellas y rosetas), motivos arquitectónicos, armas e inscripciones. Sin más demora, procederemos a comentar de manera detallada cada categoría.

\section{Barcos (Fig.13 y Lam.12)}

Contamos con un solo motivo realizado mediante técnica mixta de incisión y dibujo a carboncillo. Se localiza en el muro que recorre la galería de la crujía norte de la casa, por encima de todos los grafitos incisos del panel 5-C/SM (Fig.7).

El casco es redondo, se muestra fuera del agua y se observa claramente dibujado el perfil de la quilla, cuya línea se superpone a las almenas del castillo.Se trata de un barco probablemente de tres palos (falta el de trinquete), con las velas cuadras largadas, las costuras marcadas por la hinchazón del viento, y estandartes también cuadros y barrados en los remates. Estos estandartes ofrecen gran parecido con los que aparecen en un grafito del Castillo de Denia (BAZZAN A, LAM BLIN Y MO N TMESSIN , 1984:F.24).Tan sólo uno de los estandartes es triangular, el que se aprecia ondeando a la altura del timón, que podría tratarse de un grimpló 4 .

Las características que ofrece la embarcación, nos hace pensar que estamos ante la imagen de un barco de clara tradición medieval. Así mismo, el velamen muestra gran similitud con el de algunos grafitos de cocas y carracas de las Islas Baleares (GO N ZÁLEZ Y O LIVER, 2007) y con las de distintas naos representadas en piezas de cerámica nazarí (CASAMAR, 2005).

\section{Figuras humanas (Fig.14)}

En la estancia superior de la crujía este, encontramos incisos en los enlucidos, varios antropomorfos con faldas cuadriculadas, uno de ellos con los brazos en cruz ligeramente elevados, así como un rostro de aspecto grotesco (Fig.5, Lams. 7 y 8) de gran parecido a los personajes descubiertos en Castellfollit de Riubregós (CARBO NELL, et alii,1981). D estaca también la representación de una enorme figura, que por su atuendo y postura, parece representar a una mujer morisca que estuviera bailando (Fig.3).Su rostro aparece parcialmente cubierto. Viste tocado con adornos colgantes (tal vez borlas con flecos o joyas cosidas al tejido), zaragüelles y calza alcorques. Se pueden ver ajorcas o pulseras en su mano y le cuelga del antebrazo, lo que podría ser un cordón trenzado o un rosario (Lams. 1 a 3).

D e este motivo hemos realizado un estudio más detenido (BARRERA, 2007), donde comparamos los distintos elementos de la indumentaria de la figura, con la vestimenta de mujeres cristianas, mudéjares y moriscas representadas en grabados del siglo XVI.A demás, hemos buscado referencias de estas prendas en las fuentes escritas de la época y en modelos recientes de Marruecos.

4 D oy las gracias a Elvira González Gozalo por su inestimable ayuda y generosos consejos para el estudio de este motivo. 
Grafitos de personajes interpretados como danzantes, son las figuras del C astell d'O roners (A ger, Lleida) (BERTRÁN Y FITÉ, 1984-85) y del Castillo de la Mola (N ovelda, A licante) (NAVARRO, 1993:34-35).

En el muro que recorre la galería de la crujía norte, podemos ver inciso dentro de un círculo, junto a una de las torres del enorme castillo representado, un pequeño personaje (cabeza y torso) (Fig.14).

Posiblemente ya del siglo $X X$, por encima del panel 5-C/SM, se conserva parcialmente un personaje dibujado a carboncillo. Se dispone de perfil, tiene el cuello largo, la boca entreabierta y la nariz prominente. Sobre la cabeza lleva un pequeño sombrero decorado con rayas verticales (Fig.14 y Lam. 15).

\section{Elementos de cuenta (Fig. 13)}

Estos grafitos consisten en agrupaciones de líneas verticales consecutivas, trazadas en algunas ocasiones bajo una línea horizontal y la mayoría de las veces atravesadas por ella. Los encontramos de manera incisa y muy numerosos en los enlucidos de uno de los muros de la estancia situada en la crujía este (Fig.4 y Lam. 5). Hemos de interpretarlos como simples anotaciones, que quizás respondan a una forma arcaica de contar.

Es común que estas líneas aparezcan en recintos carcelarios, como los del Castillo de Petrer (Petrer, A licante) (N AVARRO, 1993) 0 las que hemos descubierto en laTorre del Homenaje de la Alhambra (actualmente en fase de estudio), utilizada como prisión durante los siglos XVIII-XIX, y cuya función era el cómputo del tiempo de reclusión del cautivo, autor del grafito.También aparecen junto a molinos, haciendo referencia al tiempo o turno de molienda, y en zonas de almacenaje aluden al número de productos acumulados.

Ya dijimos en otro de nuestros trabajos, que la simple agrupación y/o yuxtaposición de líneas representadas en un grafito, no bastaba para que estas fueran consideradas como "ele- mentos de cuenta", necesitaban ser legibles y agruparse de forma clara los trazos (BARRERA, CRESSIER Y MO LIN A, 1999:47).

N uestros motivos sí cumplen esas dos condiciones, principalmente los que podemos ver en la parte superior del panel 2-C/SM (Fig.4). Son auténticos "elementos de cuenta", aunque eso sí, no sabemos por ahora qué contabilizaban realmente.Tal vez productos almacenados en este espacio, 0 quizás estén relacionados con las actividades desarrolladas en él.

\section{Motivos simbólicos (Fig.15) y geomé- tricos (Fig.16)}

En esta categoría incluimos grafitos que representan motivos claramente simbólicos, como son un posible monograma de "Ave María", un corazón, cruces, estrellas, así como otros que aunque también reúnen ese mismo carácter simbólico, fueron trazados utilizando el compás, dando lugar a complejos motivos geométricos. Hablamos de rosetas hexapétalas inscritas en círculos.

\section{Ave María}

En el muro que recorre la galería de la crujía norte, donde se sitúa el panel 5-C/SM, bajo la figura de una estrella y de la puerta del gran castillo allí representado, vemos un signo geométrico que bien pudiera tratarse del monograma de "Ave María" (superposición de las letras mayúsculas M y A) (Fig.15).

\section{Corazón}

En la estancia de la crujía este, entre gran cantidad de "elementos de cuenta", localizamos igualmente inciso, una figura en forma de pica o corazón, cuyo extremo superior queda atravesado por dos líneas horizontales a modo de cruz patriarcal (Fig.4 y Lam. 6). Marcas de cantería y signos en forma de corazón rematado por una cruz patriarcal, de los siglos XVI$X V I I, y$ muy similares a nuestro motivo, se han localizado en la Lonja de Palma de Mallorca (GO N ZÁLEZ, 1989: 214, LM. 2). 


\section{Cruces}

De este símbolo cristiano es mucho lo que se podría hablar, aunque nosotros tan sólo nos vamos a centrar en un aspecto: cuando aparece representado en lugares paganos, como son grabados rupestres prehistóricos, monumentos megalíticos o edificios claramente islámicos (casas, castillos, aljibes, rábitas...), su existencia obedece a un deseo de cristianizar el espacio y hacer que desaparezca del mismo, el maligno influjo que pudiera existir.

Este fenómeno ha sido documentado ampliamente en numerosos edificios musulmanes de A Imería y Granada y se repite en la cercana muralla nazarí del Albayzín (CRESSIER, 1986; BARRERA Y CRESSIER, 2003). Posiblemente, las tres cruces incisas de perfil contorneado (tres y hasta cuatro veces) e inscritas en un doble círculo (Lam. 13 y Fig. 15), que hallamos en el panel 5-C/SM, cumplen esa función purificadora, dada la existencia de motivos claramente islámicos como son las estrellas de seis y ocho puntas, las rosetas hexapétalas y una inscripción árabe.

A parte de estos motivos cruciformes, contamos con una pequeña cruz que corona el arco dibujado en el interior de la torre del panel 4-C/SM (Fig.6 y Lam. 10), la que aparece sobre el corazón del panel 2-C/SM (Fig.4), así como la pintada a carboncillo junto al barco del panel 5-C/SM.

\section{Estrellas}

En el panel 5-C/SM vemos una estrella de seis puntas inscrita en varios círculos concéntricos, entre los que se trazan pequeños arquitos que se entrecruzan. Todo ello ha sido trazado mediante compás, pudiéndose ver en el enlucido, las marcas que señalan los centros, dejadas por la punta de este instrumento (Lam. 24).
En este mismo muro localizamos tres estrellas de seis puntas (Lam. 21), una de ellas contiene un círculo y otra se sitúa dentro de una de ocho puntas (Fig.15). Estas últimas aparecen en el interior de un doble círculo decorado con pequeños arquitos que se entrecruzan. Todo esta ejecutado a mano alzada y a semejanza del motivo trazado a compás, anteriormente descrito (Lam. 22).

Las estrellas son motivos que se representan sobre todo tipo de objetos y a lo largo de toda la historia de al-A ndalus. Éstas, en su distinta gama (de cinco puntas, de seis, de ocho, etc.), las encontramos representadas en objetos tales como piezas de vajilla, escudos, banderas, anillos, zócalos, etc., era un signo que formaba parte de la vida cotidiana de las gentes de alAndalus. Posiblemente encerraba poderes profilácticos y mágicos, tal y como se representan en talismanes y amuletos hispanomusulmanes (MARTíN EZ, 2002-2003:111-112,125; IBRAH IM, 1987; CEREZO, 2005:F.4 Y ALBARRAC ÍN , 1983).

N uestros grafitos de estrellas tendrían ese carácter mágico, al igual que las estrellas de seis y ocho puntas incisas en los enlucidos de algunos muros de Madinat al-Zahrä' (BARRERA, EN PREN SA), sobre lajas de pizarra de la ciudad califal de Vasco ( $N$ avalmoralejo, Toledo) (IZQ UIERD 0, 1994:F .62-2) y del Cerro de Marmuyas (Comares, Málaga) ${ }^{5}$ (RIU, 1981), las rupestres de Piedra Escrita (Chercos, Almería) (BARRERA Y CRESSIER, 2003:713,F.2-1), las que aparecen en bajo relieves del Castillo Górmaz (Soria) (VALDÉS,1977) y las incisas sobre tapial de fortificaciones musulmanas, como la Alcazaba de A Imería 6 (CARA,1990), el Castillo de Monteagudo (Murcia) 7 (NAVARRO Y JIMÉNEZ,1995), la misma muralla nazarí del A lbayzín (BARRERA, 2002:F.26; BARRE$R A, 2003)$ y las que estudiamos recientemente descubiertas en el Castillo de San Miguel en Almuñécar (G ranada) (BARRERA, 2008).

\footnotetext{
5 En la figura 1 podemos ver una estrella de cinco puntas.

6 En la lámina 47 podemos ver estrellas de cinco puntas en un cuadriculado. Grafitos de estrellas de cinco puntas aparecen en gran número en el Monasterio de San Millán de la Cogolla en Suso (La Rioja), denominadas por sus estudiosos (IBAÑ EZ y LEJARRAGA, 1998) "estrellas árabes". Incluso, junto a una de estas estrellas se documenta escrita la palabra "árabe" (calco I-4B).

7 En las figuras 36 y 54 podemos ver dos estrellas de ocho puntas incisas en el enlucido fresco del tapial.
} 
El hecho de que una de nuestras estrellas aparezca muy elaborada e inscrita en círculos trazados a compás, nos hace pensar que se trata de un diseño decorativo trazado en el enlucido por un alarife, con intención de aplicarlo después en algún zócalo, yesería o alfarje de la misma casa. La utilidad de este boceto decorativo no invalida el carácter profiláctico que posee.

D estacamos del panel 4-C/SM, en el que se representa la defensa de una torre mediante artillería, una culebrina que dispara su bala en dirección a una estrella de seis puntas situada en el exterior (Fig.6).

Puede ser casual que la estrella esté en la trayectoria del proyectil, pero cabe también la posibilidad de que la escena encierre un claro valor simbólico: una torre cristiana (ver arco con cruz en el interior) se defiende de un enemigo musulmán, representado por la estrella de seis puntas o Sello de Salomón.

\section{Rosetas hexapétalas}

En el panel 5-C/SM se aprecian rosetas hexapétalas inscritas en círculos concéntricos adornados con arquitos entrecruzados. Llegan incluso, a alcanzar el número de siete (número cósmico y sagrado en el Islam), las rosetas inscritas en un círculo (Lam.26).

Estas rosetas hexapétalas podemos verlas decorando modillones, capiteles y relieves de iglesias mozárabes y prerrománicas. Pero esta iconografía no es exclusiva del mundo cristiano dado que se remonta a la Edad del Bronce, siendo interpretado como un símbolo solar de carácter protector. En el mundo islámico también encontramos este símbolo, ya que Sellos de Salomón, a veces combinados con una roseta hexapétala y lazos formando trasuntos solares, se localizan en diversos edificios de Kairouan (Túnez), El Cairo (Egipto) y Amasya (Turquía) (SO UTO,1986).
Grafitos de rosetas hexapétalas, más sencillas que las nuestras, se documentan en contextos cristianos como el Monasterio de San Millán de la Cogolla en Suso (La Rioja) ${ }^{8}$ (IBAÑEZ Y LEJARRAGA, 1998), la Lonja de Palma de Mallorca (GO NZÁLEZ, 1986:F.16;GO N ZÁLEZ, 1990) y el Castillo de Petrer (Petrer,Alicante) (N AVARRO, 1993:99100). En contextos andalusíes, las encontramos como bajorrelieves en el Castillo de Górmaz (Soria) (VALD ÉS, 1977), e incisas en los subterráneos de la Torre de Comares de la Alhambra (BARRERA, 2006: FS.2, 5D), en albanegas de arcos de yeso prealmohades de Madinat Siyāsa (C ieza, Murcia) (N AVARRO Y JIMÉN EZ, 2007: F.19) y de Mojácar laVieja (Almería) (CARA, 1993:159).

Pero aparte de los numerosos ejemplos citados, consideramos al grafito que presentamos compuesto por siete rosetas inscritas en círculos concéntricos, el más interesante de nuestra serie.

Un grafito de aspecto muy similar al nuestro, aunque de mayor tamaño, apareció inciso, junto a dos rosetas hexapétalas aisladas y composiciones de círculos, en los muros exteriores de la Gran Mezquita de Divriği (1228-1229), en la región de Anatolia (Turquía). Se trata de diecinueve rosetas hexapétalas inscritas en dos círculos concéntricos. Se ha considerado este grafito como un boceto o patrón, trazado por los alarifes constructores de la mezquita, para el diseño (entre otros) de una serie de motivos circulares que decoran la fachada de la puerta $\mathrm{N}$ orte del edificio. El ornamento geométrico de estos motivos circulares, a base de hexágonos, se ha generado a partir del diseño dibujado en el grafito, siendo la unidad base del mismo, la roseta hexapétala (Fig.10) (BAKIRER, 1999).

Resulta del todo interesante ver en nuestro panel 5-C/SM esos mismos pasos seguidos por el alarife de A natolia. Por un lado, localizamos de manera aislada, lo que hemos denominado "unidades de base", es decir, grafitos de círculos concéntricos, algunos con arcos entrecruzados, estrellas de seis puntas y rosetas hexapétalas

8 Ver las figuras IV-13.1, IV-13.2, IV-66 y V-10 
(Lams. 17 a 21). Por otro lado, la combinación de esas "unidades de base", han dado lugar a los complejos motivos geométricos que presentamos (Figs. 9 y 16). Lo único que nos diferencia de la secuencia registrada en la Gran Mezquita de Divriği, es que en nuestra casa morisca no hemos localizado los motivos decorativos como tales, tan sólo sus bocetos.

Para enlazar con la siguiente categoría, nos fijaremos en esos elementos que acompañan a los motivos de estrellas y rosetas de nuestros grafitos. $\mathrm{N}$ os referimos a una serie de arquitos de medio punto entrecruzados, que se sitúan alrededor del motivo principal (estrella 0 roseta/s) a modo de orla.

Arcos de medio punto entrecruzados, esta vez en ladrillo, decoran el alminar, hoy campanario de la Iglesia de la Encarnación de Árchez (Málaga), o la puerta interior de la Justicia, la exterior de las A rmas en la A lhambra y la portada de la Alhóndiga Y̌adida o Corral del Carbón de Granada ${ }^{9}$. Es decir, elementos decorativos de clara tradición almohade, que podemos constatar en puertas de Marruecos, se repiten esta vez en edificios nazaríes. Los arquitos de nuestros grafitos serían una tardía manifestación de esa tradición islámica.

No conocemos grafitos medievales donde aparezcan este tipo de arcos, tan sólo contamos con un grafito, posiblemente del siglo X III, existente en la Iglesia del Divino Salvador de Vejer de la Frontera (Cádiz) (Fig.11), cuyo descubridor lo define como "un arco apuntado, doblado por otro de igual forma, polilobulado y entrelazado, enmarcado en un alfiz. Su origen Peninsular hay que buscarlo en el arte califal - siglo $X$-, con amplia representación con los almorávides y almohades, llegando a alcanzar su barroquismo en el siglo XIII y XIV" (ABELLÁN , 1982:138).

En definitiva, tanto las estrellas como las rosetas hexapétalas trazadas a compás, son auténticos bocetos geométricos de diseños decorativos. Diseños de clara tradición islámica y con cierto valor simbólico, que fueron realizados por un alarife, tal vez para aplicar en algún zócalo o portada de la vivienda, similares a los aparecidos en la casa morisca lindera (SAN TIAG 0, 1974) y a los que decoran la puerta principal de acceso al Patio de la Alberca en el Generalife (Fig.12) (VÍLCHEZ, 1991:46,47).

\section{Motivos arquitectónicos (Fig.17)}

Uno de ellos, corresponde a un grafito inciso que representa un enorme castillo (Fig.7 y Lam. 11). Se localiza en el muro que recorre la galería de la crujía norte de la casa (panel $5-C / S M)$. Parece haber sido realizado con un objeto (palito o caña) que ha dejado marcado en el enlucido un trazo doble, aunque nosotros a la hora de dibujar el motivo, hemos optado por el uso de una única línea. Este castillo está construido con un simulado aparejo regular de grandes sillares, merlones triangulares y doble moldura en la base de los parapetos almenados, que hace que estos vuelen sobre la vertical de las caras de las torres. Destacan una torre caballera (Lam.14) y otra con notable alambor en su base. Estas tienen ventanas y puertas en arco de medio punto, dibujándose en el interior de uno de estos arcos, la puerta de doble hoja decorada con clavos, que la cerraba.

La torre con alambor, aunque se conoce su uso a partir del siglo XII, es a mediados del siglo XV cuando se generaliza ante las nuevas técnicas pirobalísticas. En el Reino de Granada empieza a utilizarse en las fortificaciones tras la conquista castellana. Se detecta el añadido de este elemento constructivo en antiguos edificios islámicos reformados por los cristianos, como por ejemplo en los castillos de Salobreña y Gor o en laTorre de Melicena; así como en recintos fortificados cristianos de nueva construcción, de principios del siglo XVI, como el Castillo de Vélez de Benaudalla (MALPICA, 1996: 119, 190, 205, 206, 263) y el Castillo de Tahal (A Imería) (CRESSIER, 1987).

9 Se conservan incisos en el enlucido del muro exterior, arcos dobles entrecruzados de similar trazado a los que decoran en ladrillo el gran arco de la portada (Lam. 27). 
La inusual representación de castillos en la iconografía hispanomusulmana, frente a los numerosos ejemplos existentes en contextos cristianos (ya sean como grafitos, decorando cerámicas, como motivos heráldicos, en pinturas murales, en yeserías, etc.), nos induce a adjudicar una auto ría cristiana al grafito localizado. Habría que añadir que nuestro motivo y las cruces anteriormente descritas, aparecen sobrepuestos (Lams. 24 y 26) a motivos de carácter islámico con claro valor profiláctico, como las estrellas de seis puntas, las rosetas, y una pequeña inscripción árabe.

Curiosamente en la muralla nazarí del A lbayzín, levantada en tiempos de Yúsuf I, detectamos tras el estudio de los grafitos allí existentes, la participación en las obras de cautivos cristianos (BA RRERA, 2004). Se localizaron inscripciones en letra castellana gótico-cursiva que recreaban documentos públicos de la época y hacían alusión a los cautivos y su mundo, así como figuras asiduas en la iconografía medieval cristiana, tales como motivos heráldicos, peces, perros, y también castillos. En los subterráneos de laTorre de Comares en la Alhambra, hemos estudiado también, el grafito de una gran torre que representa claramente una construcción cristiana. Ésta, tiene su más cercano paralelo en laTorre de los Picos, considerada por todos los autores que la han estudiado, como una obra ajena a la tradición nazarí y de clara inspiración cristiana (BA RRERA, 2006).

Los grafitos de castillos aparecidos en la muralla y en los subterráneos de la Torre de Comares, se dibujaban simulando aparejos regulares de grandes sillares, mostraban torres almenadas con merlones rematados por triángulos y matacanes en sus esquinas. Es decir seguían los modelos o contenían elementos constructivos usuales en fortificaciones cristianas.A hora, en este nuevo grafito, no sólo vemos esos elementos, sino que podemos sumar uno más: el alambor arriba referido.

En la crujía este, junto al pie derecho de la galería de acceso a la estancia superior, descubrimos un segundo motivo arquitectónico: el diseño interior de una torre (Fig. 6 y Lam. 9) con cubierta a dos aguas, donde queda bien definida la estructura que sustentaba el tejado. La torre esta dividida en tres o cuatro plantas, construidas posiblemente mediante envigado y tarima de madera, a las que se accede con escaleras, tal vez de mano, similares a las que podemos ver en un grafito del $C$ astillo de Denia (BAZZAN A, LAMBLIN Y MO N TMESSIN ,1984:F.24). La escalera de acceso a la tercera planta, acaba en un arco apuntado con dintel, coronado por una pequeña cruz latina (Lam.10). Bajo esta pequeña estructura, se trazan en sentido vertical, varios números.

En ambos laterales de la torre y a la altura de cada piso, se pueden ver tres semicírculos dobles, que quizás representen matacanes a modo de pequeños baluartes defensivos (dibujados en planta), entre los que asoman algunas piezas de artillería.

\section{Armas (Figs. 6 y13)}

En este apartado incluimos una serie de piezas de artillería representadas en el grafito anterior. A parecen cuatro piezas bien definidas y una parcialmente conservada.

Por el aspecto que ofrecen, parece que se trata de piezas ligeras, de gran longitud de tubo 0 ánima y fabricadas de una sola pieza. En cuatro de las cinco piezas, podemos distinguir dibujados muy esquemáticamente, elementos como los muñones y la lámpara rematada por el cascabel. En dos de las piezas vemos la cureña, así como el esbozo de ruedas en otras dos.

C reemos que estamos ante la representación de piezas de artillería del género culebrina, que constituye la pieza característica del siglo XVI.

Efectivamente, en este siglo surgen algunas innovaciones. Por ejemplo, las piezas de artillería ya no constan de dos partes separadas, como las bo mbardas o lombardas (MELERO, 1993), sino que son de una sola pieza, reduciendo de este modo los escapes de gases que se producían entre la caña y la recámara. D el mismo modo, aparecen los muñones como elementos que 
sirven de eje de giro a la boca de fuego. Con el aumento de la longitud de los tubos, se aprovechaba al máximo la fuerza de los gases producidos en la combustión de la pólvora, siendo mayor el alcance de la bala.

La culebrina poseía un alcance máximo de disparo de 450 m., cargaba balas de 16 a 30 libras (7,5 a $14 \mathrm{Kg}$.) y tenían una longitud de ánima de 25 á 35 calibres, llamándose legítima la de 30. A unque las culebrinas estuvieron presentes en el campo de batalla, se emplearon más desde las fortalezas.

A pesar de que consideremos culebrinas las armas representadas en nuestro grafito, no resulta fácil identificar qué tipos de piezas artilleras son, ya que existían distintos modelos dependiendo del peso y calibre que tenían. A nte la cantidad de calibres existentes en aquella época, y el problema que ello suponía, "Miguel de Herrera, Capitán General de la Artillería, planteó a Carlos I, en 1534, establecer siete clases de calibres y piezas: cañones, medios cañones, culebrinas, medias culebrinas, sacres, falconetes y medios falconetes, clasificación que el emperador aceptó" (GONZÁLEZ, 1997).

Es de gran interés observar como en la primera planta de la torre representada, una culebrina dispara un proyectil esférico. N os consta que las culebrinas y cañones utilizaban balas esféricas, macizas y de hierro, pero también otras envueltas en estopa que se incendiaban e iluminaban el campo, llamadas balas de fuego.

Algunos ejemplos de grafitos, aunque datados en el siglo XVIII, que representan piezas de artillería, unas disparando bo las esféricas y otras situadas en fortalezas, han sido descubiertos en el campanario de la Catedral de Mallorca (BERN AT, GO N ZÁLEZ Y SERRA,1986:F.59), en el Castillo de Bellver (Palma de Mallorca) ${ }^{10}$ (GONZÁLEZ Y RO SELLó ,2006) y en el Salón del Trono de la A ljafería (Zaragoza) (ROYO Y GÓ MEZ,2002:7475, FS.10,11).

\section{Inscripciones}

Por ahora, tan sólo podemos adelantar, que por encima de la taca derecha de la estancia situada en la planta primera, en la crujía norte, encontramos junto a varios círculos incisos en el enlucido, tres inscripciones que aparentemente parecen estar escritas en caracteres latinos.

En cambio, junto a los motivos de estrellas y de rosetas hexapétalas del Panel 5-C/SM, localizados en esa misma crujía, aparece una inscripción árabe de pequeño tamaño (Fig.8 y Lam. 16). Así mismo, sobre uno de los alcorques que lleva la mujer morisca representada en el grafito descubierto en la estancia de la crujía este (Panel 1-C/SM), podemos ver otra inscripción, al parecer también en caracteres árabes (Lam. 4).

De las inscripciones árabes, aún no podemos ofrecer una trascripción, dado que serán objeto de estudio en otro momento por parte de un especialista en la materia. Estudio, que permitirá, entre otros aspectos, comprender mejor la superposición detectada de los grafitos.

Por último, debemos de incluir en este apartado los números " $4,6,5,6,5$ " del panel $4-C / S M$ y las series de letras y números "I 8 I", "t r L 9 I" y "P L 96 I", todas ellas dentro de recuadros, del panel 5-C/SM.

\section{CONCLUSIONES}

Valgan las siguientes líneas, como primeros resultados, de los distintos motivos descubiertos, ya que actualmente estamos realizando estudios más detenidos de ellos, que serán dados a conocer en próximos trabajos.

Hallamos por un lado, motivos que podemos relacionar con una sociedad claramente islamizada, como las estrellas de seis y ocho puntas, las rosetas hexapétalas, ambas de carácter mágico o profiláctico, las propias inscripciones 
en árabe, así como el grafito que representa una mujer morisca bailando con el rostro parcialmente cubier to y con su típica indumentaria (tocado con colgantes, alcorques, zaragüelles, ajorcas y collar o rosario). El dibujo de esta mujer morisca, junto con los otros grafitos de personajes que aparecen en la misma estancia, no es más que la plasmación en un muro de la casa, de un momento festivo en la vida cotidiana del siglo XVI. En al-Andalus, la música y la danza estaban unidas a festividades como la ruptura del ayuno, bodas o nacimientos, y se constata incluso en época morisca, la participación en estos eventos de mujeres bailando.

La importancia de las rosetas hexapétalas y las estrellas estudiadas, radica en que constituyen verdaderos bocetos geométricos de diseños decorativos, trazados en el enlucido del muro por un artesano o alarife diestro en el uso del compás. O bservando los grafitos, podemos rastrear los pasos seguidos por el alarife para llegar a conseguir los motivos más complejos: se localizan estrellas de seis puntas y rosetas hexapétalas aisladas, así como simples círculos concéntricos, para finalizar con complicadas combinaciones de todos estos elementos (Fig. 9). Se trata de una auténtica "clase de geometría", destinada quizás, a la elección de distintos diseños decorativos, de clara tradición islámica, para aplicar en algún otro lugar de la casa, posiblemente en un zócalo.

Ya documentamos en los enlucidos de la muralla nazarí del Albayzín y en los subterráneos de la Torre de Comares, bocetos arquitectónicos trazados por alarifes, ahora se trata, como hemos visto, de diseños decorativos geométricos.

Respecto al barco descubierto, decir que la arquitectura naval que ofrece es de clara tradición medieval, aunque por el contexto donde aparece, hemos de situarlo en el siglo XVI. $Q$ uizás, como ya dijimos, pudiera tratarse de una embarcación emparentada con los barcos redondos del tipo carraca o nao.
Por otro lado, la iconografía cristiana queda representada con el posible monograma de "A ve María", con varias cruces contorneadas, otra patriarcal sobre un corazón y un pequeño arco apuntado coronado por una cruz latina. Los propios motivos arquitectónicos localizados ( gran castillo y torre defensiva) constituyen por sí mismos y contienen, elementos claramente cristianos, entre otros, la torre con alambor y los baluartes defensivos con piezas de artillería (culebrinas).

No debemos olvidar la interesante "escena simbólica" representada en el panel 4-C/SM, donde una culebrina dispara su bala a una estrella de seis puntas o Sello de Salomón, que podríamos interpretar como la defensa de una torre cristiana frente a un enemigo musulmán. No sería descabellado considerar esta escena como el relato de cualquier hecho, de los tantos que en aquel siglo XVI se produjeron por estas tierras, quizás relacio nado con la Guerra de los Moriscos (1568-1571).

A parte de los grafitos incisos de series de letras y números y el personaje con sombrero y los "elementos de cuenta" dibujados a carboncillo del panel 5-C/SM, trazados posiblemente en el siglo XX, podemos aventurarnos a datar el conjunto de los grafitos de la casa, en el siglo XVI. Fueron realizados en un momento de abandono o reocupación de la casa morisca. Son el reflejo de una época convulsa donde conviven dos culturas muy distintas y antagónicas.

Para terminar, decir que queda mucho camino por recorrer en el estudio de los grafitos históricos de Granada. La documentación de estos motivos sólo será posible con la estrecha colaboración entre arqueólogos, arquitectos, y los que nos dedicamos al estudio de estas manifestaciones gliptográficas. De esta manera, podremos confeccionar un Corpus de motivos, que por sí mismo, constituirá un documento histórico de primera mano, que desvelará aspectos, a veces desconocidos, de la historia de nuestra ciudad y de los hombres que la habitaron. 


\section{BIBLIOGRAFIA}

ABELLÁN PÉREZ, Juan (1982): “El graffiti medieval de la Iglesia Parroquial del Divino Salvador de Vejer de la Frontera". Estudio de Historia y Arqueología, II, pp. 137.140.

ALBARRACÍN NAVARRO, Joaquina (1983): “El sello de Salomón en uno de los manuscritos árabes inéditos de 0 caña (Toledo)". I Congreso Internacional de las Tres Culturas, Toledo, pp. 105-115.

A RDU IN I, D avid y GRASSI, Chiara (2002): Graffiti di navi medievali sulle chiese di Pisa e di Lucca. D ialoghi del Gruppo Archeologico Pisano. Felici Editore

BAKIRER, Ö mür (1999): "The Story of Three Graffiti". Muqarnas: An Annual on the Visual Culture of the Islamic World. XVI, pp. 42-69.

BARRERA MATURAN A, José Ignacio (2002): "Graffiti en la muralla del Albayzín". Arqueología y Territorio Medieval, 9, pp. 289-328.

BARRERA MATURAN A, José Ignacio (2003): “Los graffiti de la muralla islámica de Granada". I Congrés Internacional de Gravats Rupestres i Murals, Lleida 1992. Lleida, pp. 721-733.

BARRERA MATURAN A, José Ignacio (2004): “Participación de cautivos cristianos en la construcción de la muralla nazarí del Albayzín (Granada): sus graffiti". Arqueología y Territorio Medieval, 11.1, pp. 125-158.

BARRERA MATURAN A, José Ignacio (2006):" «Trazados de edificios moros»: graffiti medievales en los subterráneos de la Torre de Comares de La A lhambra". Arqueología y Territorio Medieval, 13.1, pp. 197-217.

BARRERA MATURAN A, José Ignacio (2007): "Representación de una mujer morisca en un graffiti del Albayzín (Granada)". Anaquel de Estudios Árabes, 18, pp. 65-91.

BARRERA MATURANA, José Ignacio (2008): “Grafitos medievales en Granada", Arqueología, Historia y Viajes sobre el Mundo Medieval, no 22 (Febrero), EDM Revistas, pp. 30-39.

BARRERA MATURAN A, José Ignacio (en prensa):“N uevos graffiti en Madinat al-Zahra ${ }^{-\prime \prime}$. Cuadernos de Madinat al-Zahrä

BARRERA MATURAN A, José Ignacio y CRESSIER, Patrice (2003): "G rabados parietales y rupestres de Almería: Un problema de cronología". I Congrés Internacional de Gravats Rupestres i M urals, Lleida 1992, Lleida, pp. 709-720.

BARRERA MATURAN A, José Ignacio,CRESSIER, Patrice y MO LIN A MUÑ OZ, José A ntonio (1999): “G arabatos de alarifes: Los graffiti de las galerías de desagüe de Madinat al-Zahrä"'. Cuadernos de Madinat al-Zahrā', 4, pp. 39-81.
BAZZANA, André., LAMBLIN, Marie-Pascale y MO N TMESSIN , Yves (1984): Los graffiti medievales del Castell de Denia. Catálogo. Denia (Alicante).

BERN AT i RO CA, Margalida, GONZÁLEZ GOZALO, Elvira y SERRA i BARCELÓ, Jaume (1986): “Els graffiti del campanar de la Seu de Mallorca". Estudis Baleárics, 23, IV, pp. 7-46.

BERTRÁN i RO IGE, Prim y FITÉ i LLEVOT, Francesc (1984-85): "Primera aproximació a la cerámica grisa i als "graffiti" del Castell d'O roners (Áger, Lleida)". Acta Mediaevalia, 5-6, pp. 387-418.

CAÑ AVATE TO RIBIO, Juan (2006): Granada, de la medina nazań a la ciudad cristiana. Editorial Universidad de Granada. Granada.

CARA BARRIO NUEVO, Lorenzo (1990): La Almería islámica y su alcazaba. Almería.

CARA BARRIO N UEVO, Lorenzo (1993): La civilización islámica. Historia de Almería 3. Almería.

CARBO N ELL i ESTELLER, Eduardo, CARRERAS i SAN TAFÉ, Pilar, CA SA N O VAS i RO MEU, Ängels, CIURA N ETA i MURGARELLA, M.Teresa, FERN ÁN DEZ i A SPAS, N eus, FERRAN i GÓ MEZ, Doménec, GO NZÁLEZ i VERDAGUER, Teresa, LLARÁS USÓ N, Celina, MARTÍN EZ i MO RGEN STERN , Cristina, REY-STO LLE DEGO LLADA, Cecilia, RIU i BARRERA, Eduard, RO IG i DEULO FEU, Albert, RO SELL i G ILBERT, Roser y TO BIAS SÁN CHEZ, Imma (1981): “Los grafitos de Castellfollit de Riubregós. Primeras aportaciones". Quaderns d'estudis medievals, II, 5, pp. 278-310.

CARBO N ELL RELAT, Laureano (1986):"La «coca», nave del medioevo". Revista de Historia Naval. Año IV, no 15 , pp. 45-64.

CARBO N ELL RELAT, Laureano (1989):"Las dos piedras con naves en relieve de la catedral y torre inclinada de Pisa". Revista de Historia Naval. Año VI, no 24, pp. 71-104.

CARDA ILLAC -H ERMO SILLA,Y vette (2005):Los nombres del diablo. Ensayo sobre la magia, la religión y la vida de los últimos musulmanes en España: los moriscos. Colección Biblioteca de Bolsillo Divulgativa, núm.24, Universidad de Granada.

CASAMAR PÉREZ, Manuel (2005): "Zafas nazaríes con representaciones de naos". Cuadernos de la Alhambra, vol.41, pp. 22-35.

CEREZO PO N TE, Carmen (2005):"Señuelo para investigadores". Anales del Museo de América, 13, pp. 339-358.

CHOCAN $O$ HIGUERAS, Guadalupe (1990): “Las naves de Colón". Revista de Historia Naval. Año VIII, no 29, pp. 63-82. 
CRESSIER, Patrice (1986): “G raffiti cristianos so bre monumentos musulmanes de la Andalucía O riental: U na forma de exorcismo popular". I Congreso de Arqueología M edieval Española, Huesca 1985. T. I, Zaragoza, pp. 273-291.

CRESSIER, Patrice (1987):"Prospección A rqueo lógica en la Sierra de los Filabres y el Alto Valle del A Imanzora (5-20 de agosto 1985)". Anuario Arqueológico de Andalucía 1985 T.ll, Sevilla, pp. 71-80.

FERN ÁN DEZ DEL CERRO, Jacobo (2007): "A bandono, reocupación y reforma de una casa hispanomusulmana entre los siglos XI y XIV. Los graffiti de Calle Lócum, 15 (Toledo)" en Jean Passini y Ricardo Izquierdo (Eds.). La ciudad medieval de Toledo: Historia, Arqueología y Rehabilitación de la Casa. El Edificio Madre de Dios. U. de Castilla La Mancha., pp. 113-138.

GO N ZÁLEZ ALCALDE,Julio (1997):“La media culebrina del marqués de los Vélez. La transición de la artillería de hierro a la de bronce". Militaria. Revista de Cultura Militar, 10, pp. 365-376.

GO N ZÁ LEZ GO ZALO, Elvira (1986): "G raffiti a la Torre de Sant Joan de la Llotja". Bolletí del Institut d'Estudis Baleàrics, IV, 23, pp. 47-56.

GO N ZÁLEZ GO ZALO, Elvira (1989): “Los graffiti de la Lonja de Palma de Mallorca. Signos e inscripciones (I)". Actas du Vle Colloque Internacional de Glyptographie de Samoëns, 1988, C I.R.G., Braîne-le'C hâteau (Bélgica), pp. 195-226.

GONZÁLEZ GO ZALO, Elvira (1990): “Los graffiti de la Lonja de Palma de Mallorca (España) (2)". Actes du VIllème Colloque Internacional de Glyptographie du Rochefort-Sur-M er, 1990, C .I.R.G., pp. 123-133.

GONZÁLEZ GOZALO, E. (1993): "Tipos náuticos en los graffiti mallorquines (siglos XIV- XIX)", Actes du IXe Colloque International de Glyptographie d'Hoepertingen (Egregio)1992, C .I.R.G ., Braine-le-C hâteau, pp. 255-271.

GONZÁLEZ GOZALO, Elvira y PASTOR Q UIJADA Xavier (1994): «La arquitectura naval en los graffiti medievales mallorquines». IV Congreso de Arqueología Medieval Española. A licante 1.993, t. III, pp. 1.035-1.047.

GO N ZÁLEZ GO ZALO, Elvira y O LIVER FO NT, Bernat (2007): Los Barcos de Piedra. La arquitectura náutica balear a través de los grafitos murales (siglos XIV-XVIII).Institut d'Innovació Empresarial de les Illes Balears. Govern de les Illes Balears.

GONZÁLEZ GOZALO, Elvira y RO SELLÓ PONS, Magdalena (2006): Los grafitos de la Torre del Homenaje del Castillo de Bellver. Ayuntamiento de Palma, Castillo de Bellver y Lleonard Muntaner.
IBÁÑ EZ RO DRÍGUEZ, Miguel y LEJÁRRAGA N IETO, Teodoro (1998): Los grafitos del Monasterio de San Millán de Suso. Consejería de Educación, Cultura, Juventud y Deportes de Logroño.

IBRA HIM,Tawfiq (1987): "Evidencias de precintos y amuletos en al-Andalus". II Congreso de Arqueología M edieval Española, Madrid, T. II, pp. 705-710.

IZQ UIERD O BEN ITO ,Ricardo (1994): La ciudad hispanomusulmana de "Vascos" N avalmoralejo (Toledo). Campañas 1983-1988. Toledo-Madrid.

LÓ PEZ GUZMÁN , Rafael (2007):“La arquitectura doméstica granadina en los inicios del siglo XVI", en Jean Passini y Ricardo Izquierdo (Eds.). La ciudad medieval de Toledo: $\mathrm{H}$ istoria, Arqueología y Rehabilitación de la Casa. El Edificio Madre de Dios. U. de Castilla La Mancha., pp. 17-34.

MA LPIC A CUELLO,A ntonio (1996): Poblamiento y castillos en Granada. Lunwerg Editores, Barcelona.

MA RM O L CA RVAJA L, Luis del (1600): H istoria del rebelión y castigo de los moriscos del Reino de Granada. Editorial Arguval, Málaga, 1991.

MARTÍN EZ EN AMO RAD 0, Virgilio (2002-2003): “Una primera propuesta de interpretación para los plomos con epigrafía árabe a partir de los hallazgos de $\mathrm{N}$ ina Alta (Teba, provincia de Málaga)". Al-Andalus-M agreb, 10, pp. 91-127.

MELERO, Ma. Jesús (1993): “La evolución y empleo de armamento a bordo de los buques entre los siglos XIV al XIX". M ilitaria. Revista de Cultura Militar, 5, pp. 45-66.

NAVARRO PALAZÓN, Julio y JIMÉNEZ CASTILLO, Pedro (1995): "El Castillejo de M onteagudo: Qasr Ibn Sad", en Casas y Palacios de Al-Andalus. Siglos XII-XIII. Madrid, pp. 63-103.

N AVARRO PALAZÓ N, Julio y JIMÉN EZ CASTILLO, Pedro (2007): Siyāsa: estudio arqueológico del despoblado andalusí (ss. XI-X III). Fundación El Legado Andalusí, Granada.

N AVARRO POVEDA, Concepción (1993): Graffitis y signos lapidarios del Castillo de la M ola (N ovelda) y del Castillo de Petrer. Excmo. Ayuntamiento de Novelda e Instituto de Cultura "Juan G il-Albert" (D ip. Prov. de Alicante), Petrer (Alicante).

O RIHUELA UZAL, Antonio (2007): "Restauración de casas andalusíes en Granada", en Jean Passini y Ricardo Izquierdo (Eds.). La ciudad medieval de Toledo: Historia, Arqueología y Rehabilitación de la Casa. El Edificio Madre de Dios. U. de Castilla La Mancha., pp. 213-233.

O RIHUELA UZAL,Antonio (2008):"Casas Moriscas" en Unos apuntes sobre la Granada Andalusí, por la EEA en su 75 Aniversario. Artículo de prensa en D iario Ideal del 08-02-08, p. 7 . 
RíU RíU, Manuel (1981):“Consideraciones sobre la cuarta campaña arqueoló gica realizada en 1.979 en el Cerro Marmuyas (Montes de Málaga)".Al-Qantara, II, pp. 429-448.

ROYO GUILLÉN, José Ignacio y GÓ MEZ LECUMBERRI, Fabiola (2002): "Panorama general de los "graffiti" murales y de los grabados al aire libre medievales y post-medievales en Aragón". Al-Qannis, Boletín del Taller de Arqueología de Alcañiz, 9, pp. 55-156.

SANTIAGO SIMÓN, Emilio de (1974): "Restos de un zócalo morisco en una casa del Albaicín". Miscelánea de estudios Árabes y Hebraicos, Vol. XXIII, Fasc. 1ํ, pp. 121-123.

SEC O DE LUCEN A, Luis (1910): Plano de Granada Árabe. Edición facsímil de Los Libros del Caballero Andante, no 3. Editorial D on Q uijote, Granada, 1982.
SO UTO LASALA, Juan A ntonio (1986): "Marcas de cantero, graffiti y signos mágicos en el mundo islámico: panorámica general". Actas del V Coloquio Internacional de Gliptografía, CIRG, Pontevedra, pp. 463-486.

TO RRES BALBAS. Leopoldo (1936): “Los modillones de lóbulos. Ensayo de análisis de la evolución de una forma arquitectónica a través de diez y seis siglos". O bra dispersa, II,Archivo Español de Arte yArqueología, Instituto de España, 1981, pp. 241-289.

VALDÉS FERN ÁN DEZ, Fernando (1977): "Relieves musulmanes de carácter profiláctico en la fortaleza de Górmaz (Soria)". XIV Congreso Nacional de Arqueología (Vitoria 1975), Zaragoza, pp. 1275-1278.

VÍLCHEZ VÍLCHEZ, Carlos (1991): El Generalife. Granada. 


\section{GRAFITOS HISTÓRICOS}

LOCALIZACIÓN: CASA DE CALLE SAN MARTÍN, № 16, ALBAYZIN (GRANADA)

FECHA DE DOCUMENTACIÓN: 23-03-05,18-08-06 y 26-08-06

SITUACIÓN: En la primera planta. En el muro exterior de la sala de la crujía Norte, en el espacio que se desarrolla en la galería superior, hacia la derecha de la puerta.

SOPORTE: En el enlucido de yeso del muro.

TÉCNICA DE EJECUCIÓN:

\begin{tabular}{|l|l|}
\hline INCISIÓN & Incisión fina. \\
\hline DIBUJO & \\
\hline PUNTEO & \\
\hline IMPRESIÓN & \\
\hline REPICADO & \\
\hline
\end{tabular}

IDENTIFICACIÓN DE INSTRUMENTO EN EL TRAZADO: Utilización de compás.

MEDIDAS: AMS: $152 \mathrm{~cm}$. y a $149 \mathrm{~cm}$. de la jamba derecha de la puerta. Circunferencia mayor de $11 \mathrm{~cm}$. de diámetro. La menor $6,5 \mathrm{~cm}$. y los arquitos entrecruzados de $2 \mathrm{~cm}$.

TEMÁTICA: Roseta hexapétala inscrita en círculos concéntricos decorados con arquitos entrecruzados. Los extremos de los pétalos se unen mediante trazos curvos.

CRONOLOGÍA: Siglo XVI.

OBSERVACIONES: Se puede ver un motivo arquitectónico (castillo) superpuesto.

\section{FOTOGRAFÍA}

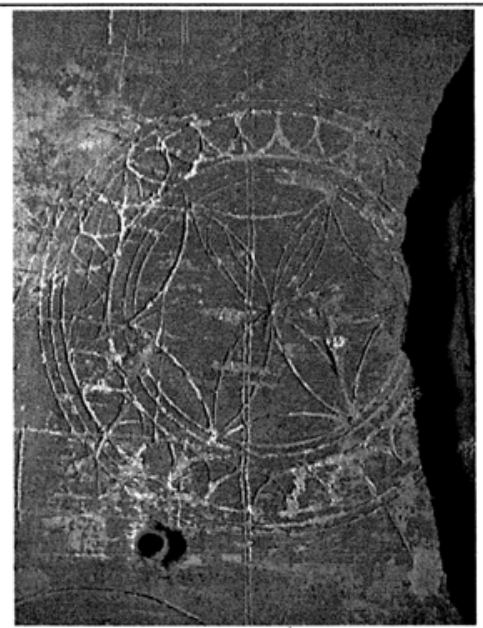

\section{DIBUJO}

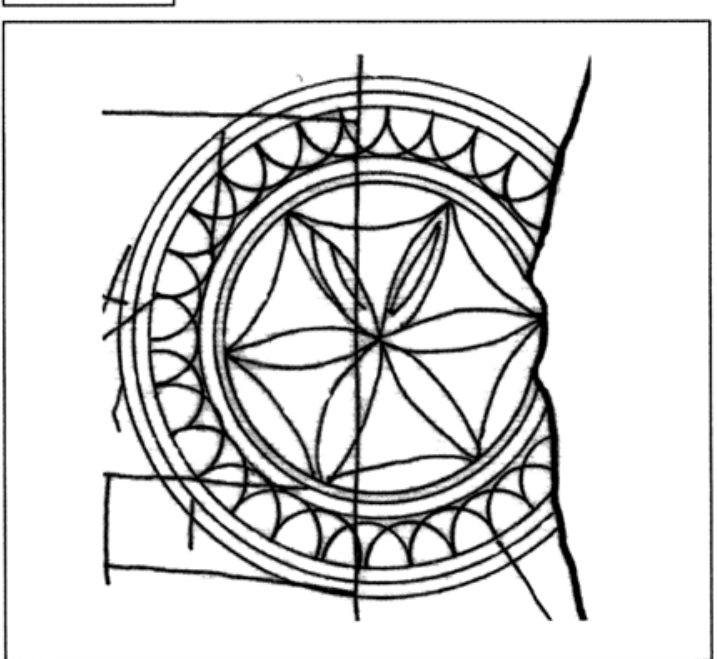

Fig.1. Modelo de ficha de catalogación. 


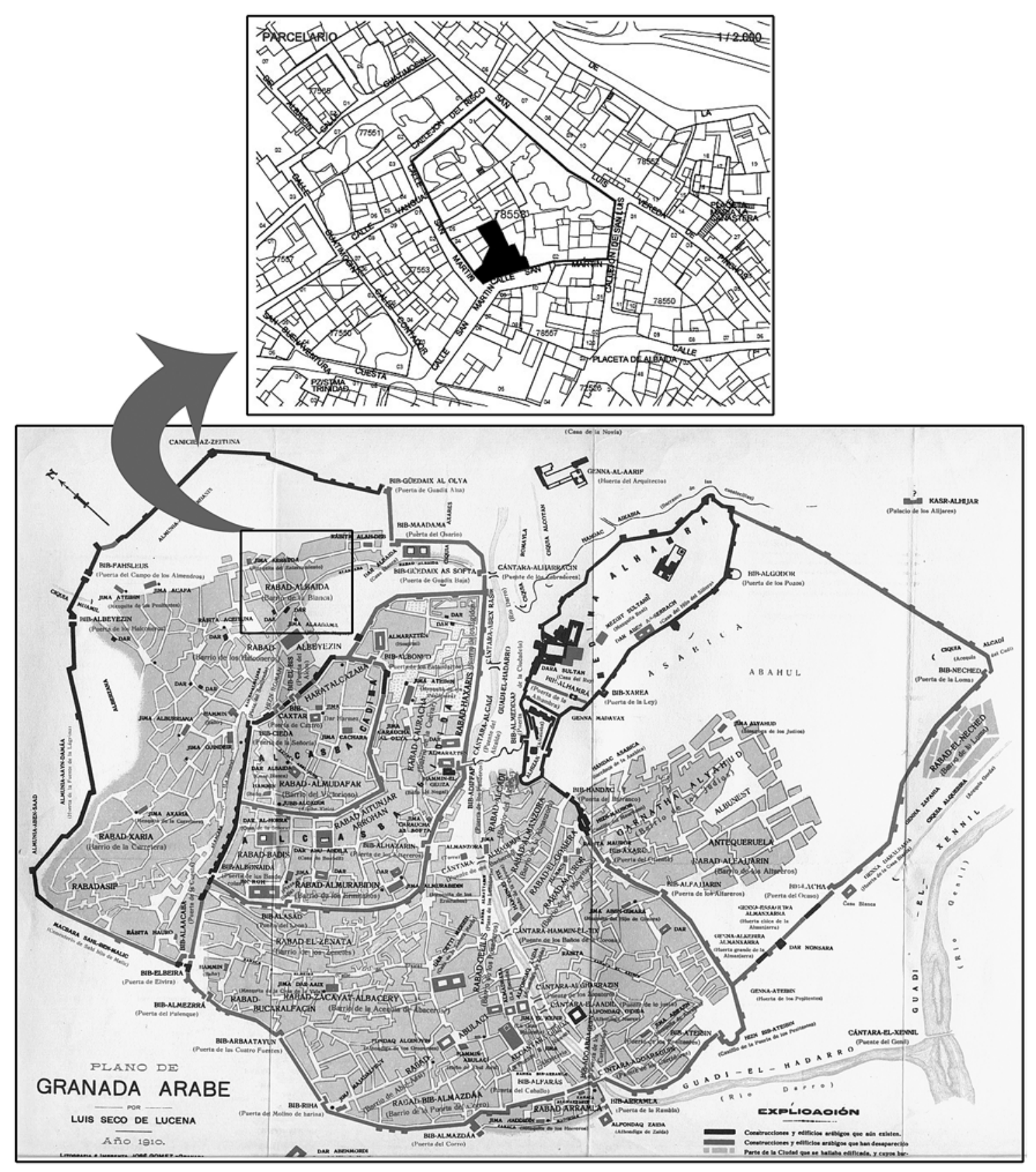

Fig. 2. Plano de situación de la casa morisca. 


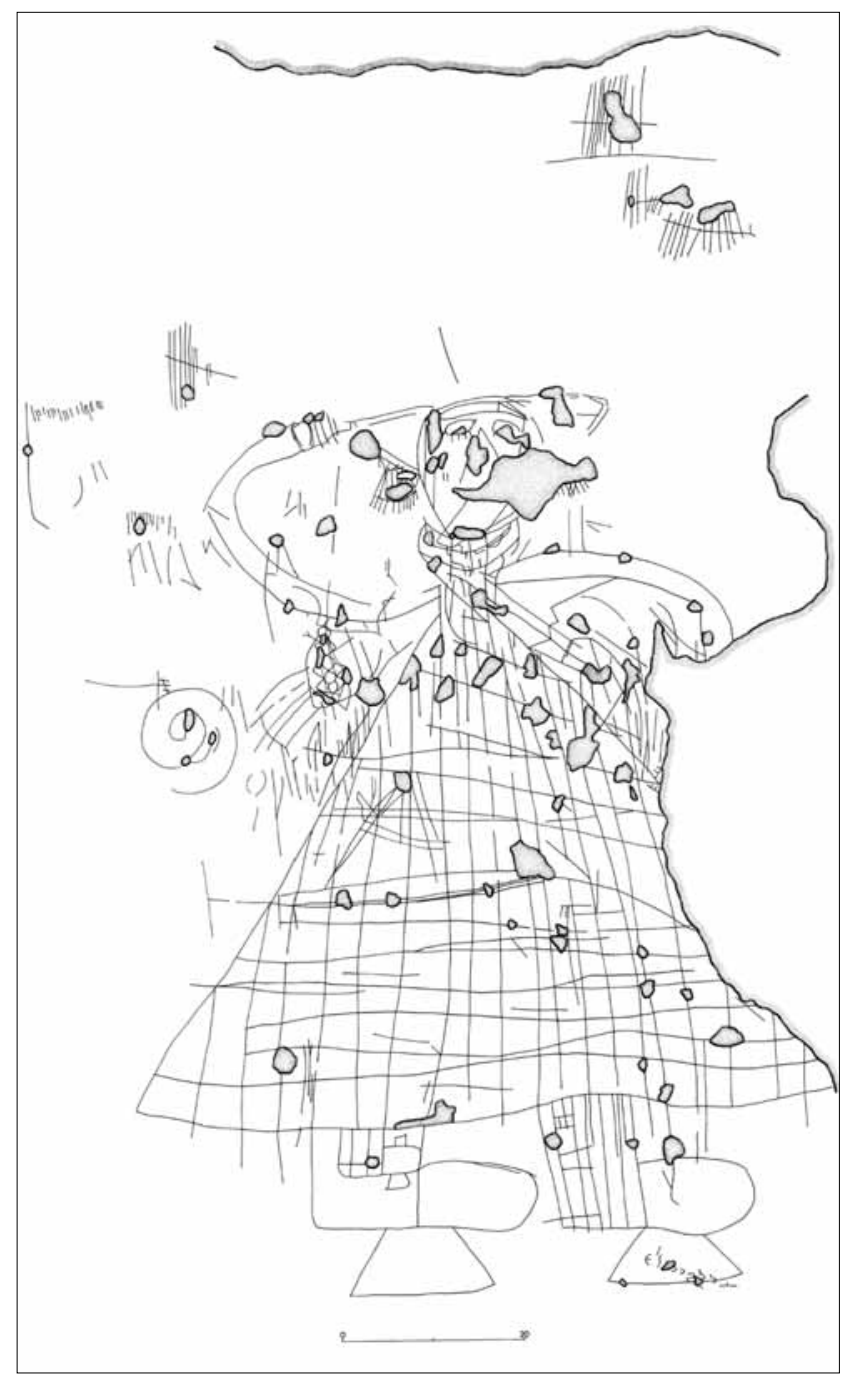

Fig. 3. Panel $1-C / S M$.

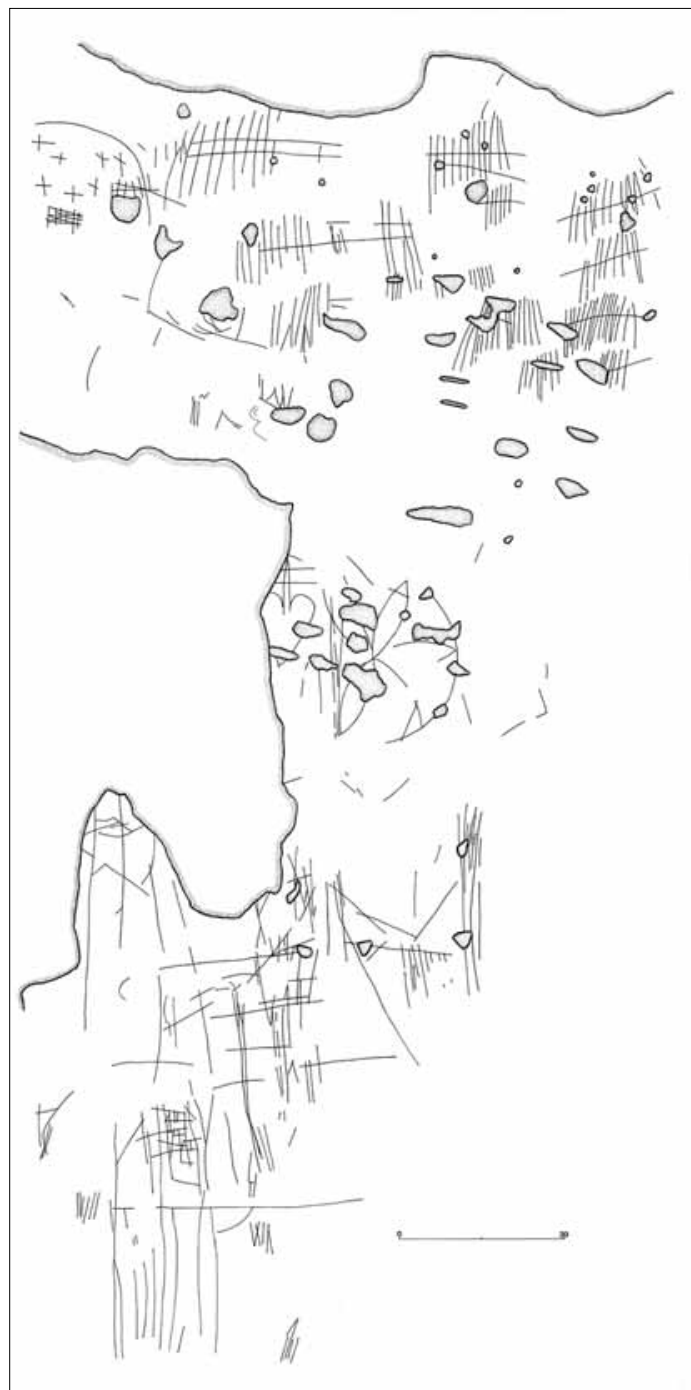

Fig.4. Panel 2-C/SM . 
Fig. 5. Panel 3-C/SM.

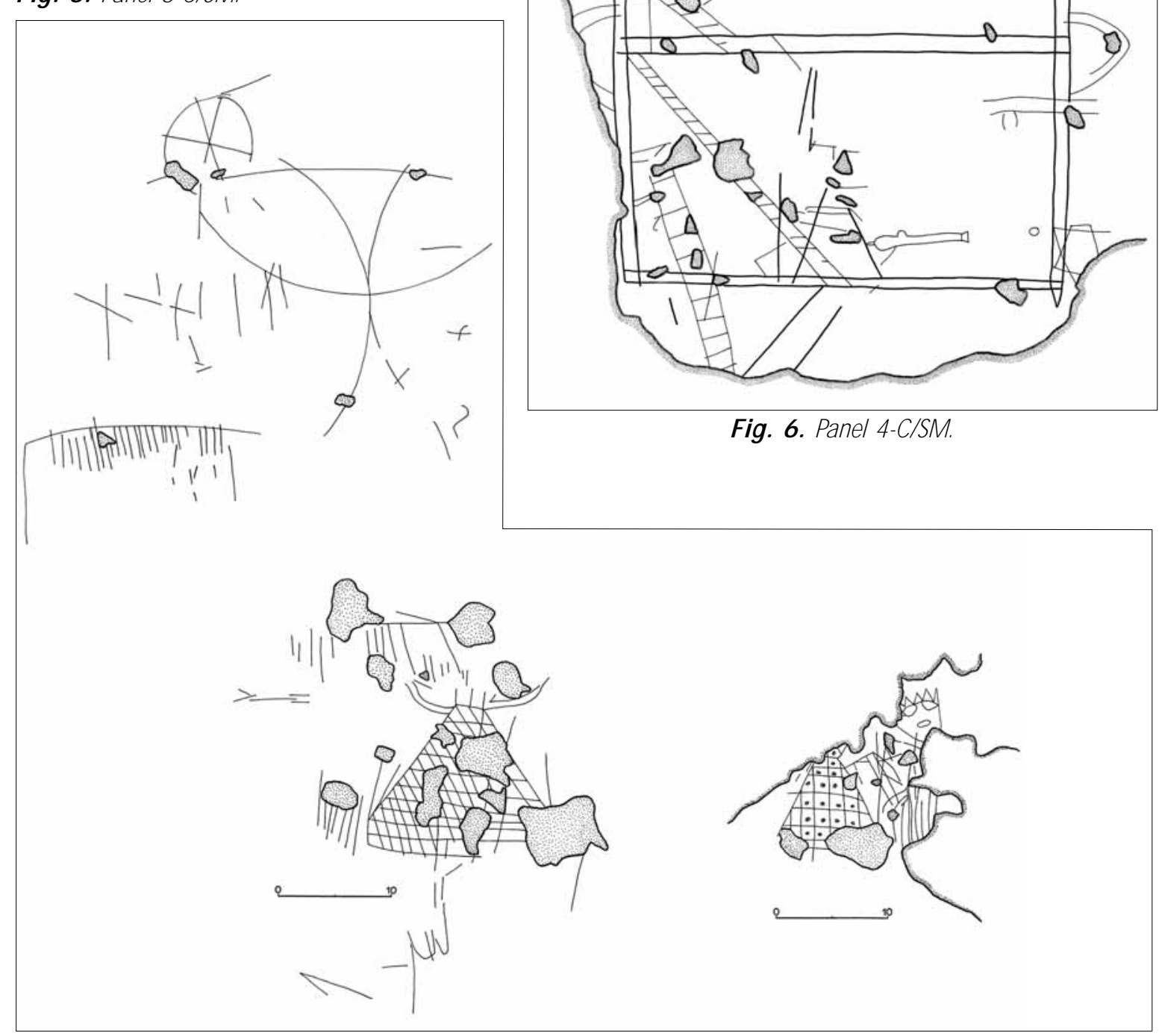




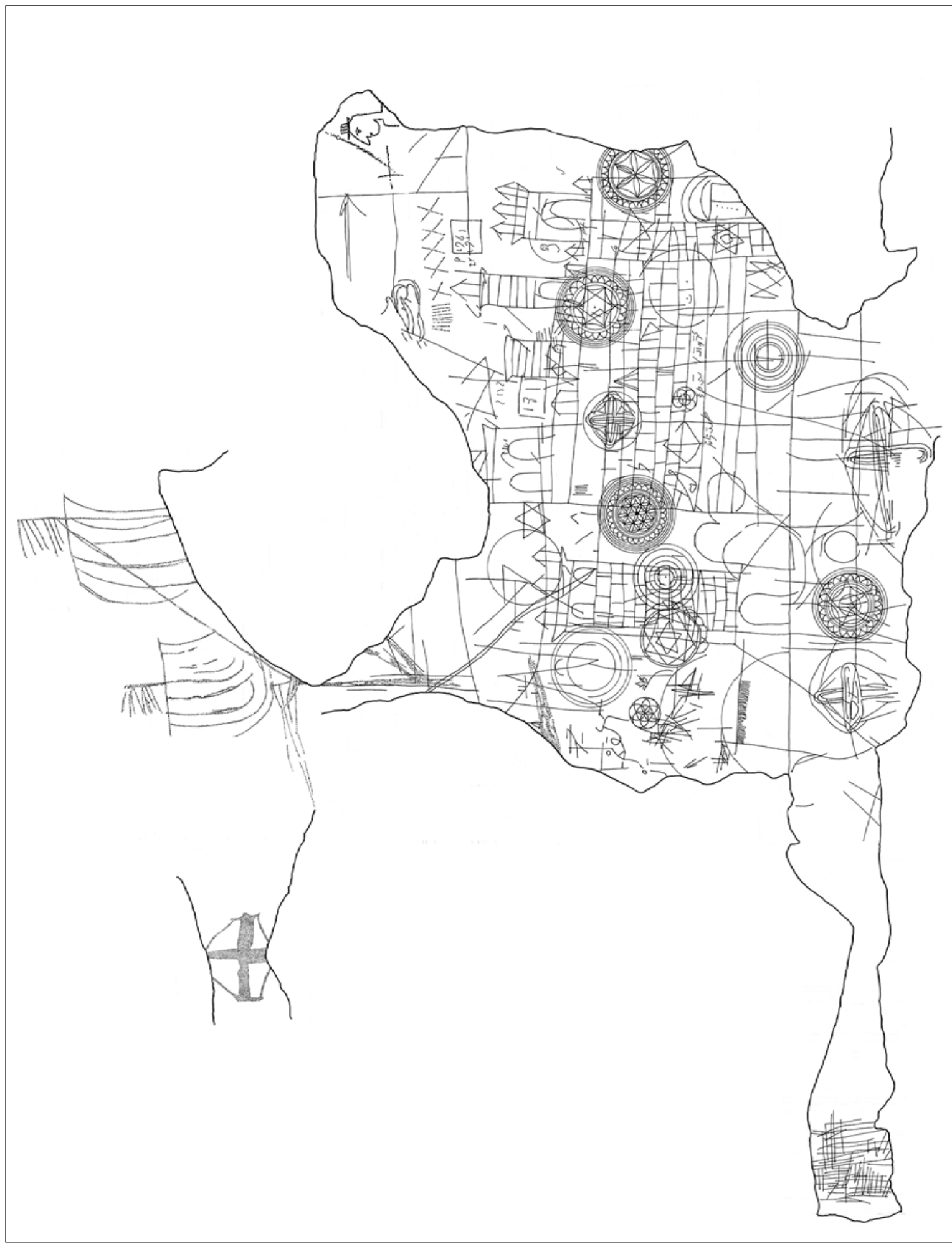

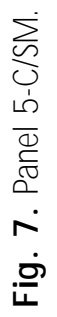




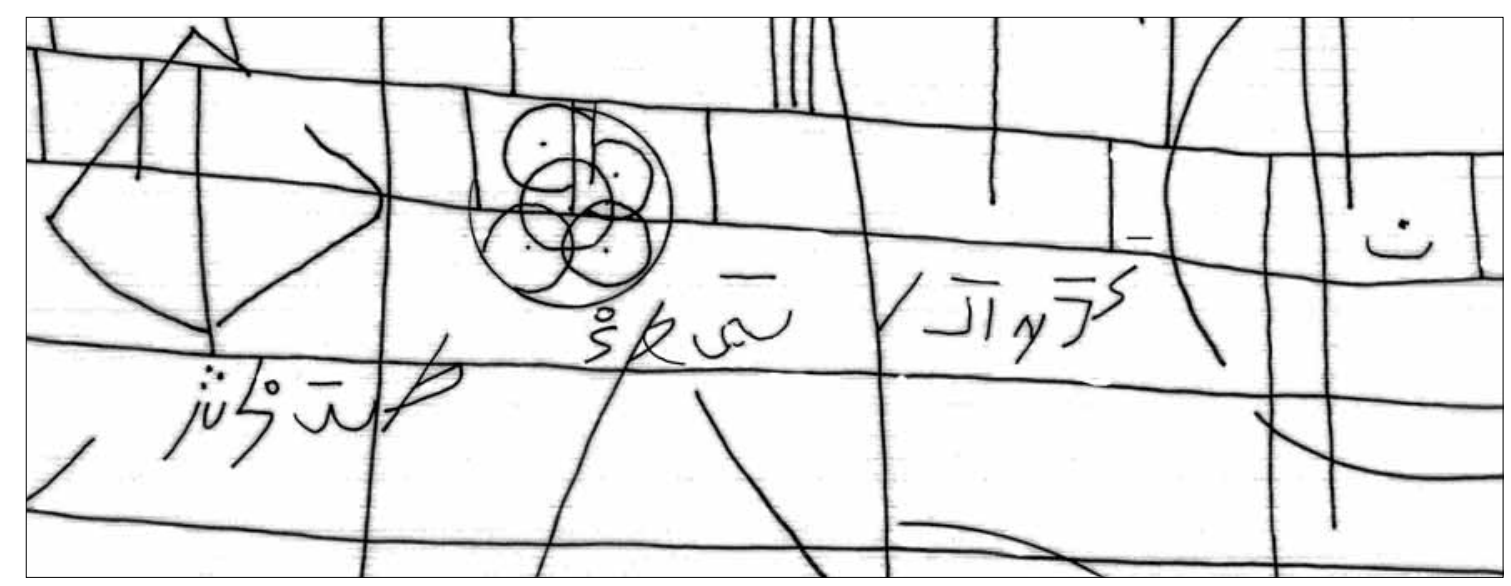

Fig. 8. Inscripción árabe. Panel 5-C/SM .

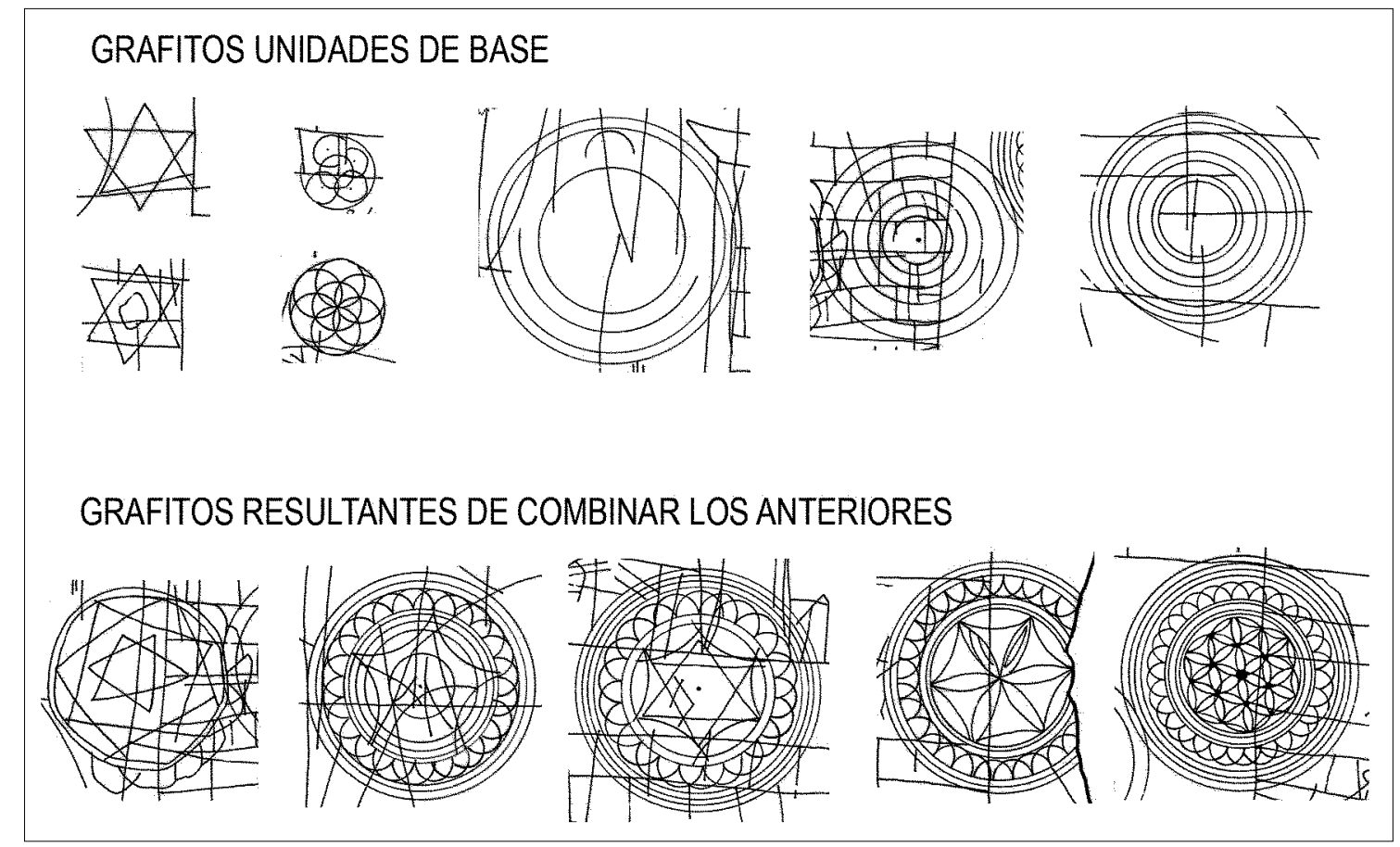

Fig. 9. Secuencia de los grafitos del Panel 5-C/SM . 


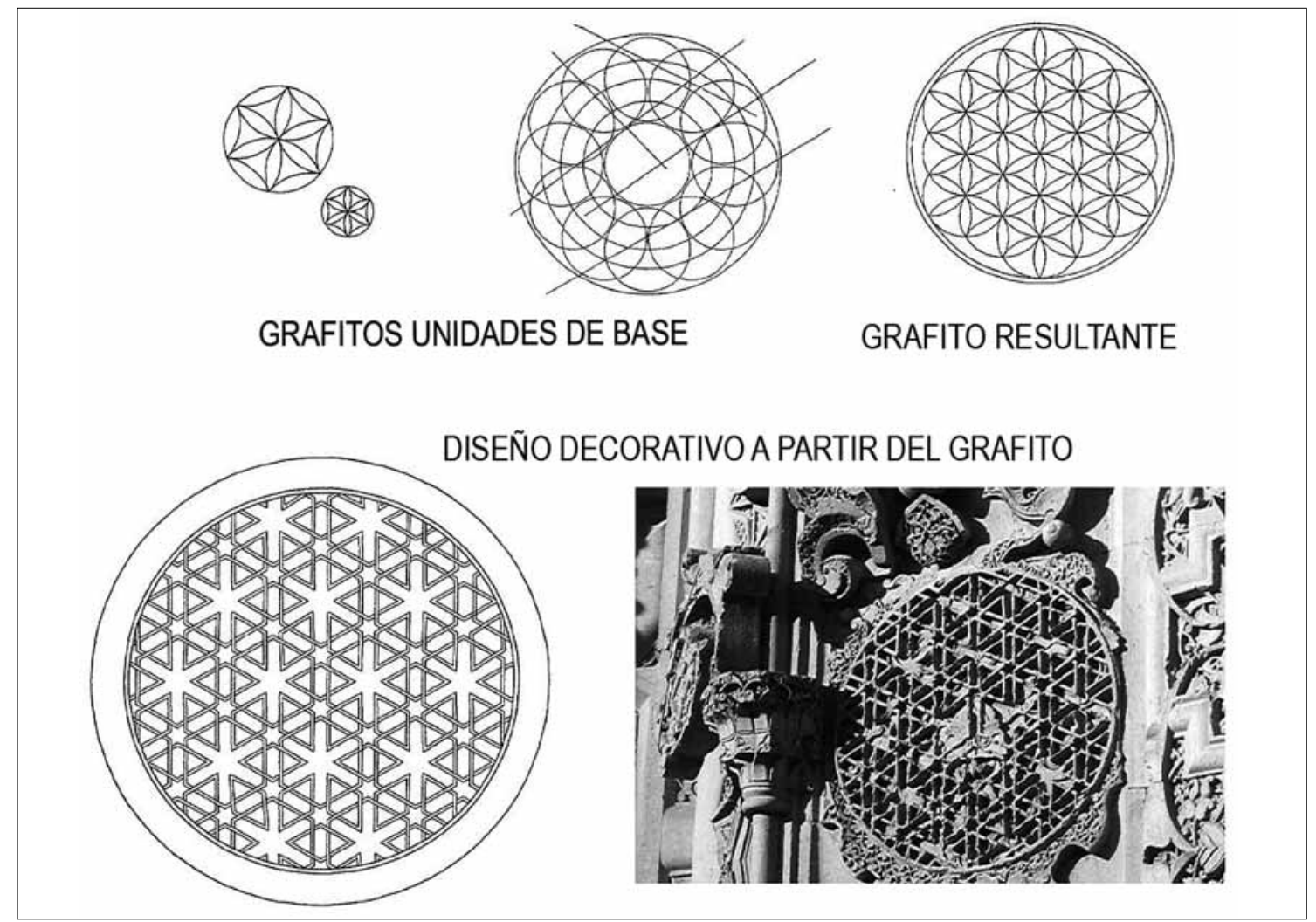

Fig. 10. Secuencia de los grafitos de la Gran Mezquita de Divriği (Siglo XIII).

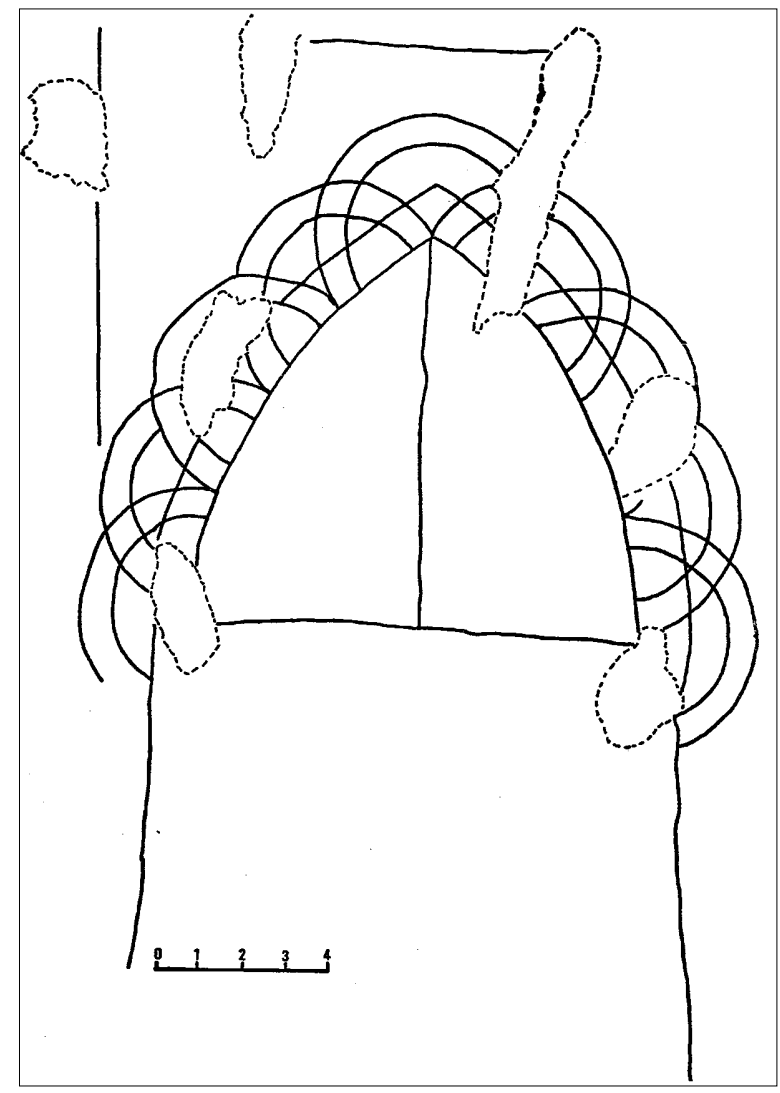

Fig. 11. Grafito en la Iglesia del Divino Salvador de Vejer de la Frontera (Cádiz).

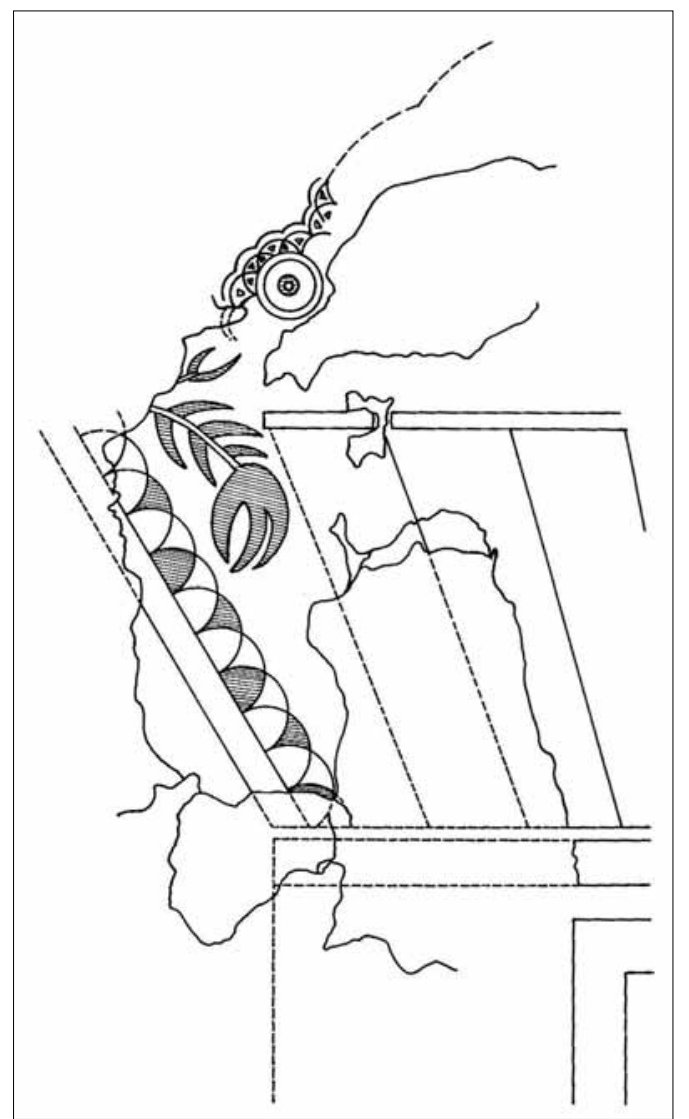

Fig. 12. Decoración pintada del Generalife. 


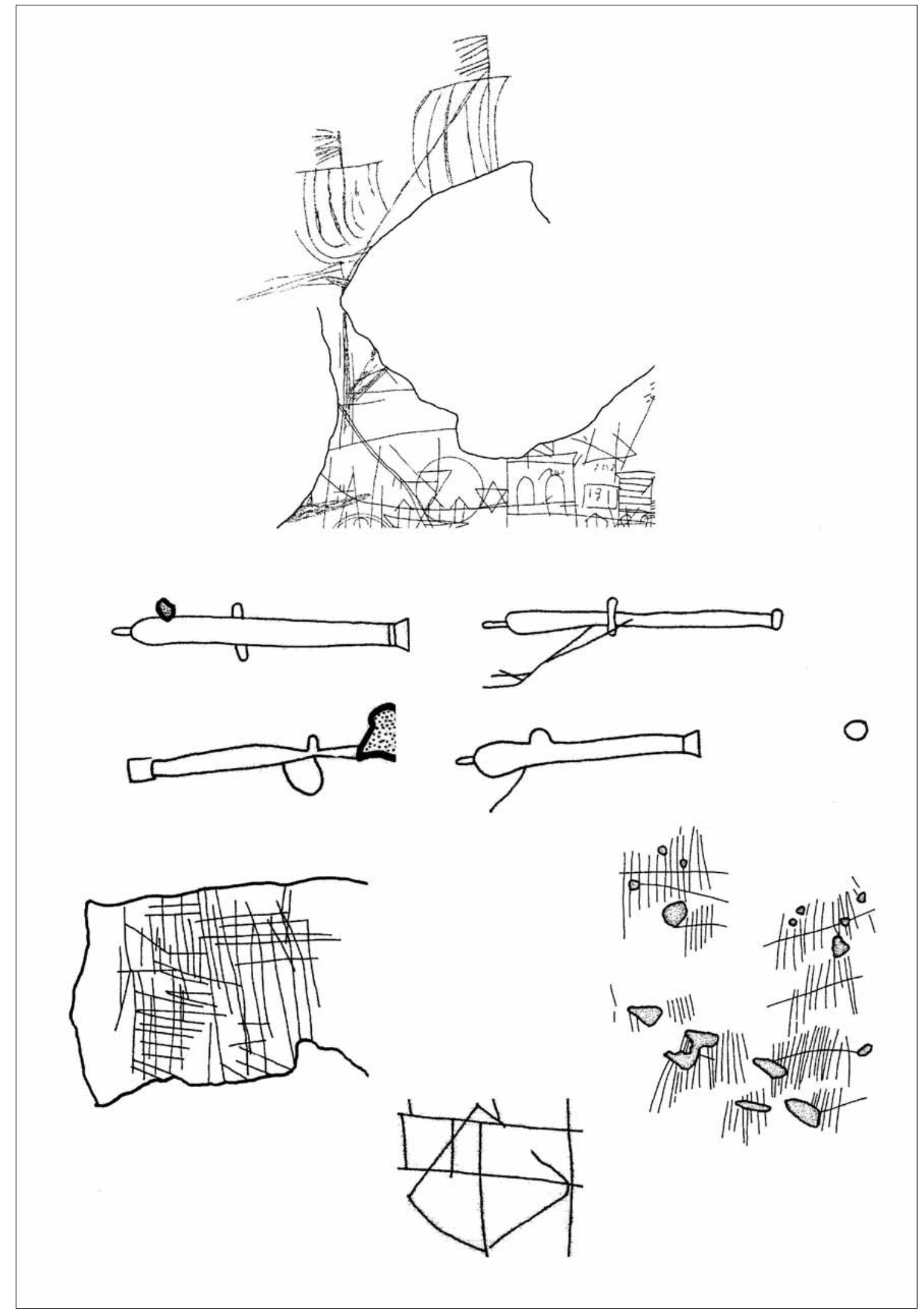

Fig. 13. Barco, armas, líneas entrecruzadas, elementos de cuenta y rombo. 

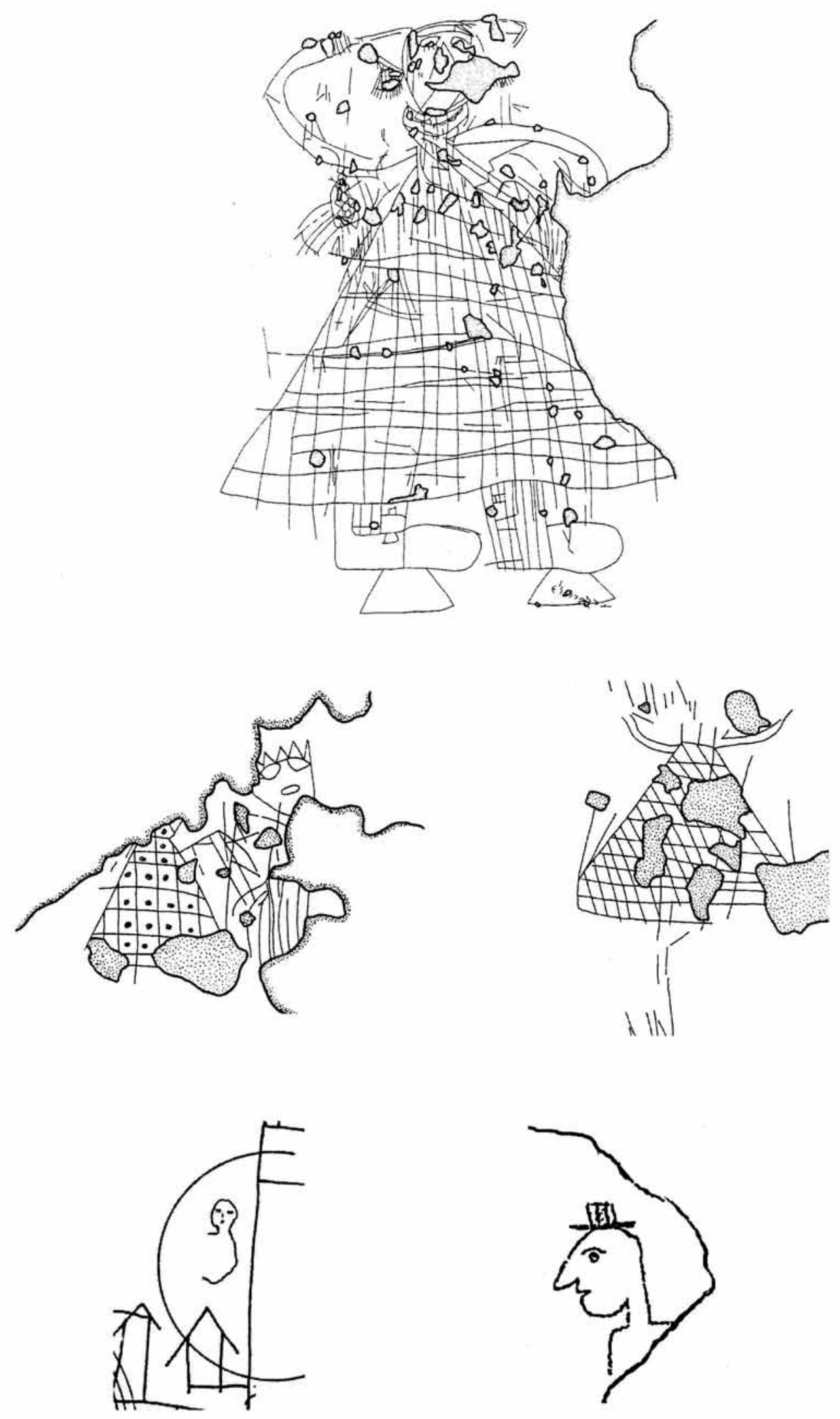

Fig. 14. Figuras humanas. 

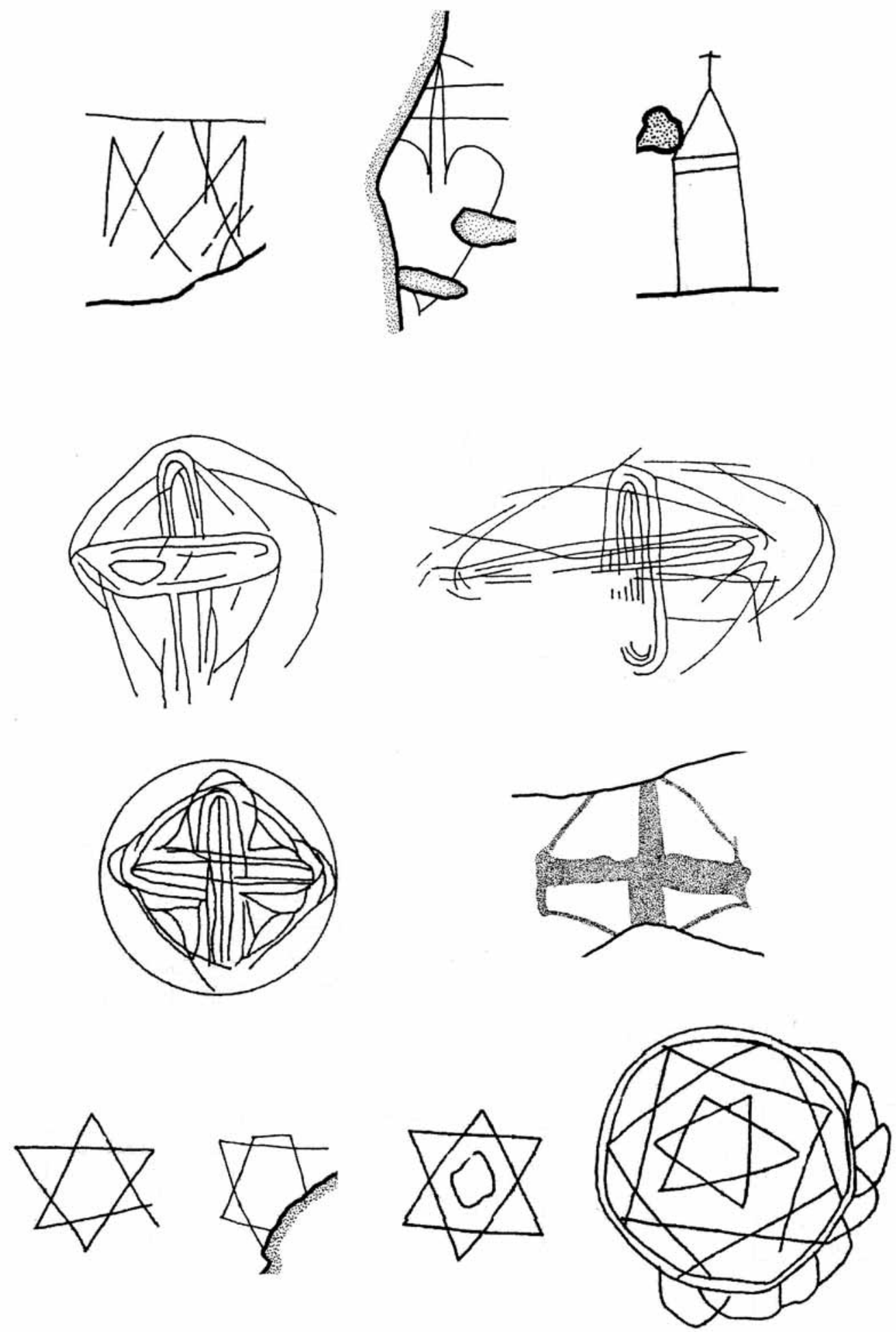

Fig. 15. Motivos simbólicos: Ave María, corazón, cruciformes y estrellas. 

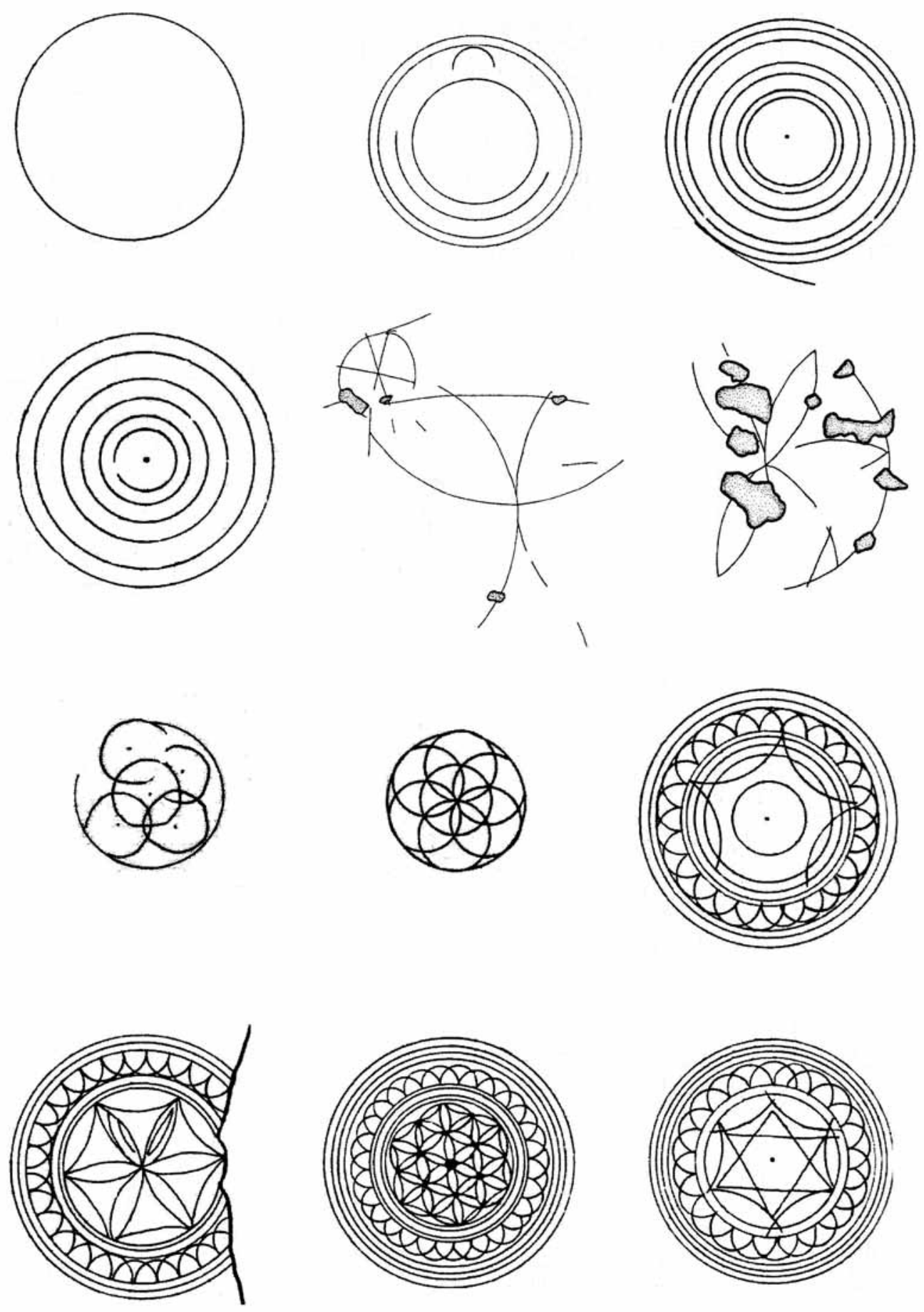

Fig. 16. Círculos y motivos geométricos trazados a compás. 


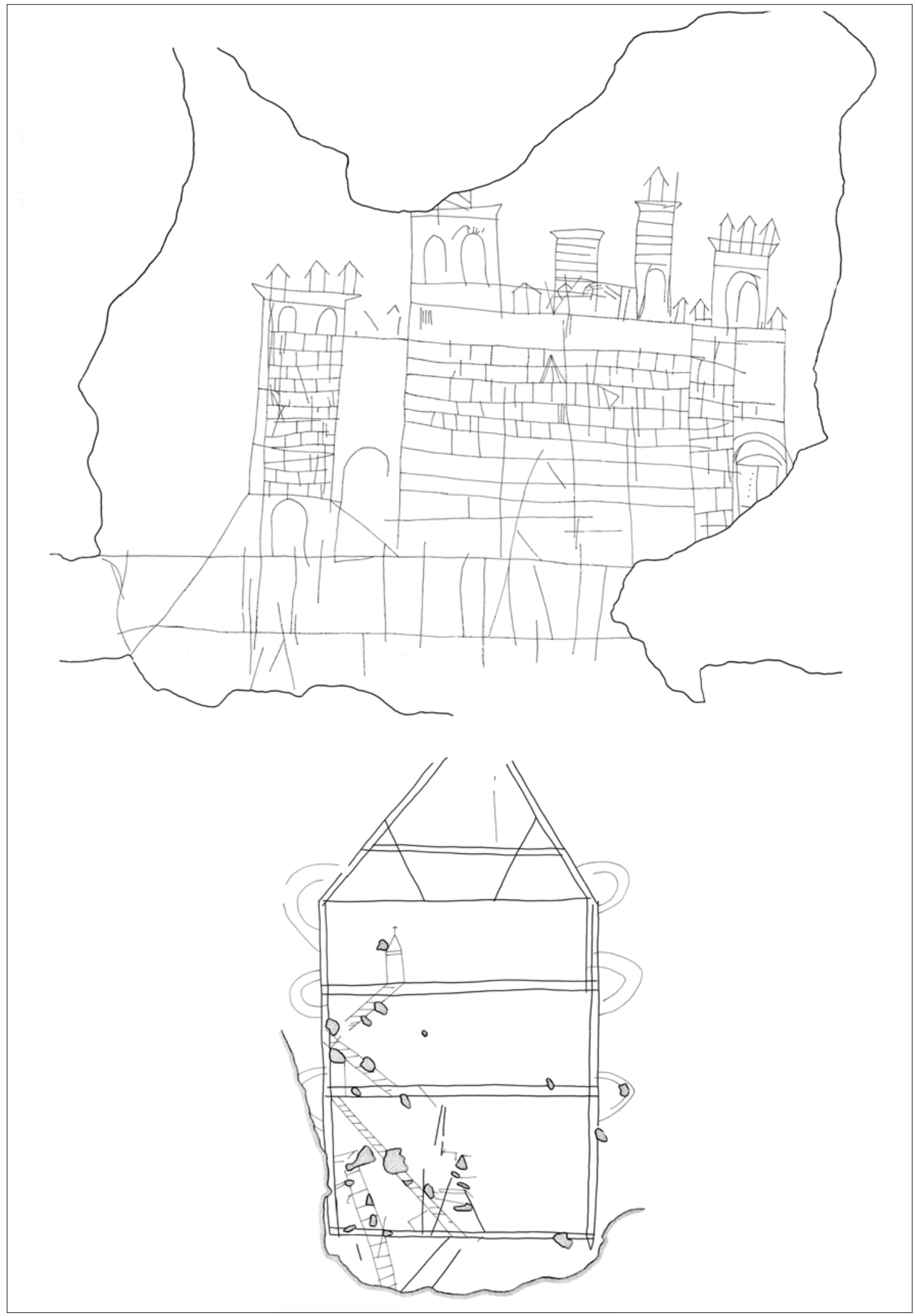

Fig. 17. Motivos arquitectónicos: castillo y torre. 


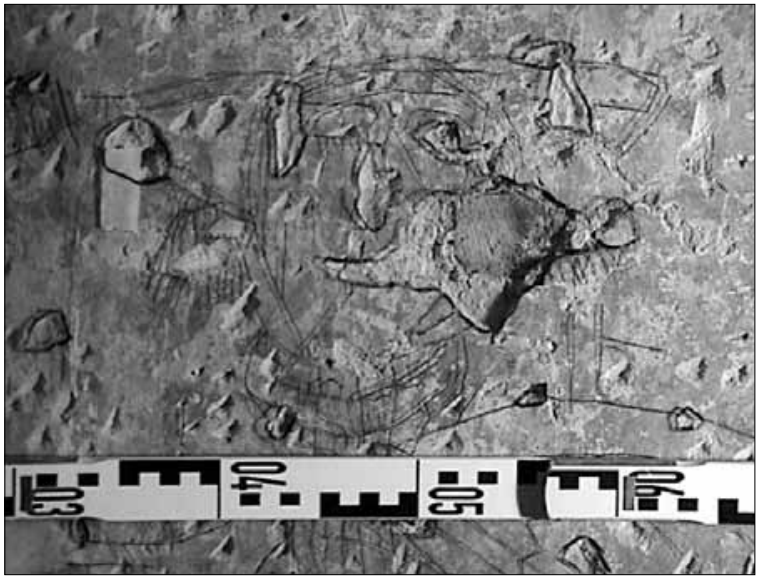

Lam.1. Cabeza de la mujer morisca durante el proceso de calco. Panel 1-C/SM.

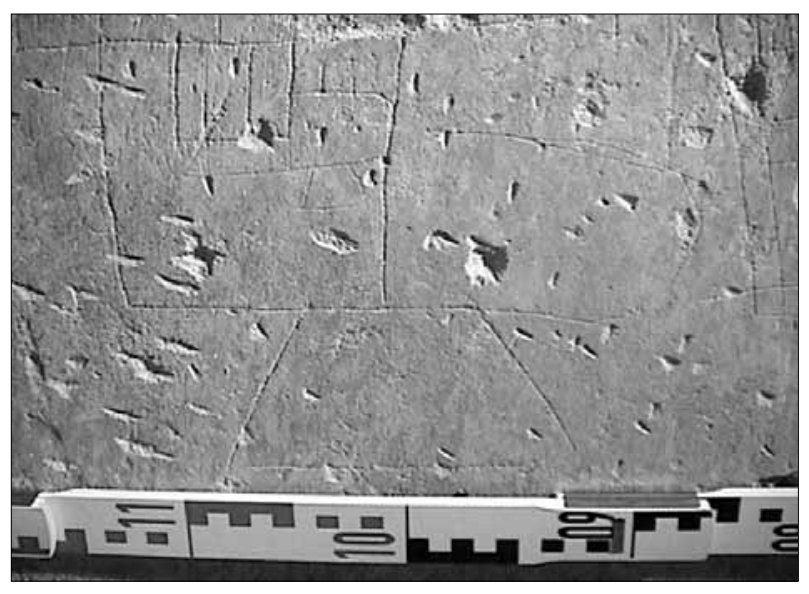

Lam. 3. Detalle de los alcorques de la mujer morisca. Panel 1-C/SM.

Lam. 4. Inscripción en el alcorque de la mujer morisca. Panel 1-C/SM.

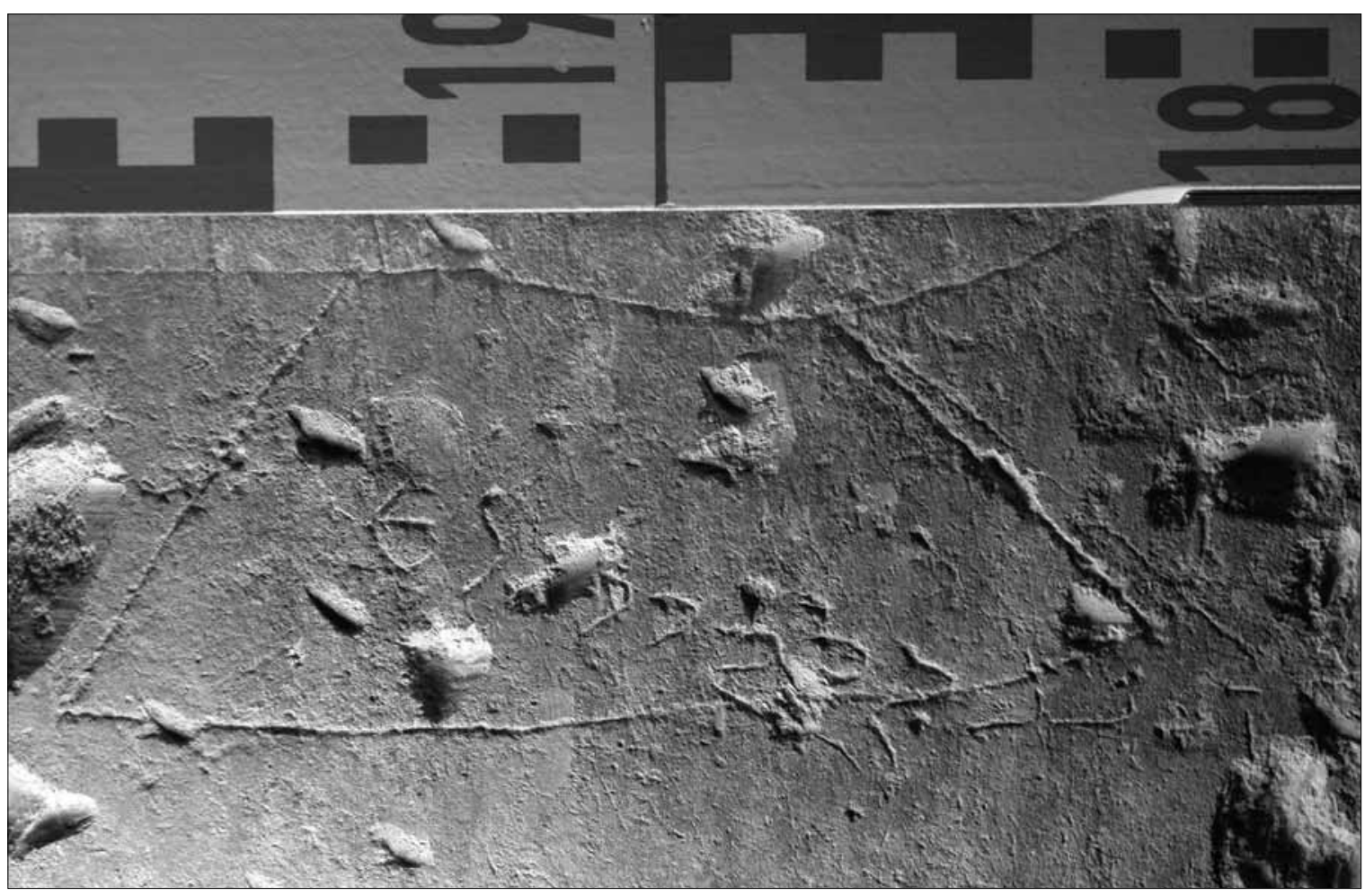




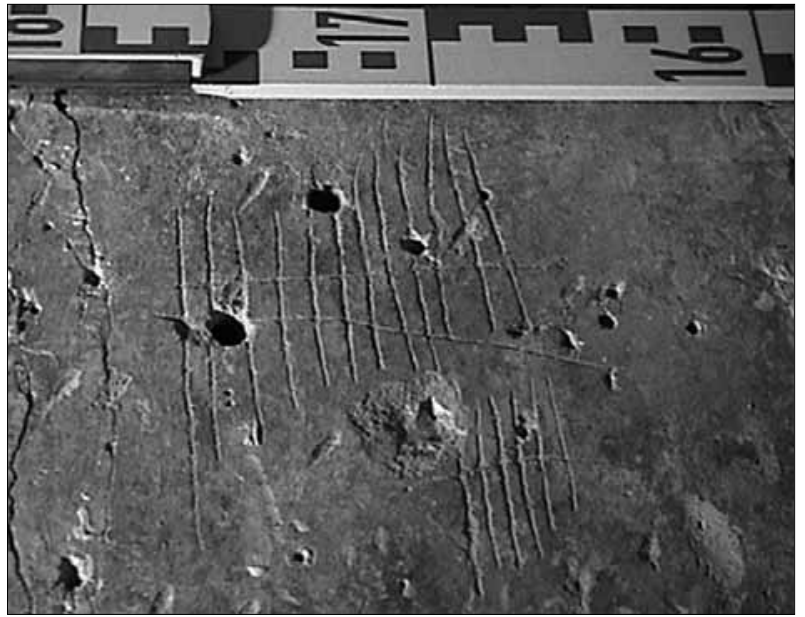

Lam. 5. Elementos de cuenta. Panel 2-C/SM .

Lam. 6. Cruz patriarcal sobre corazón. Panel 2-C/SM
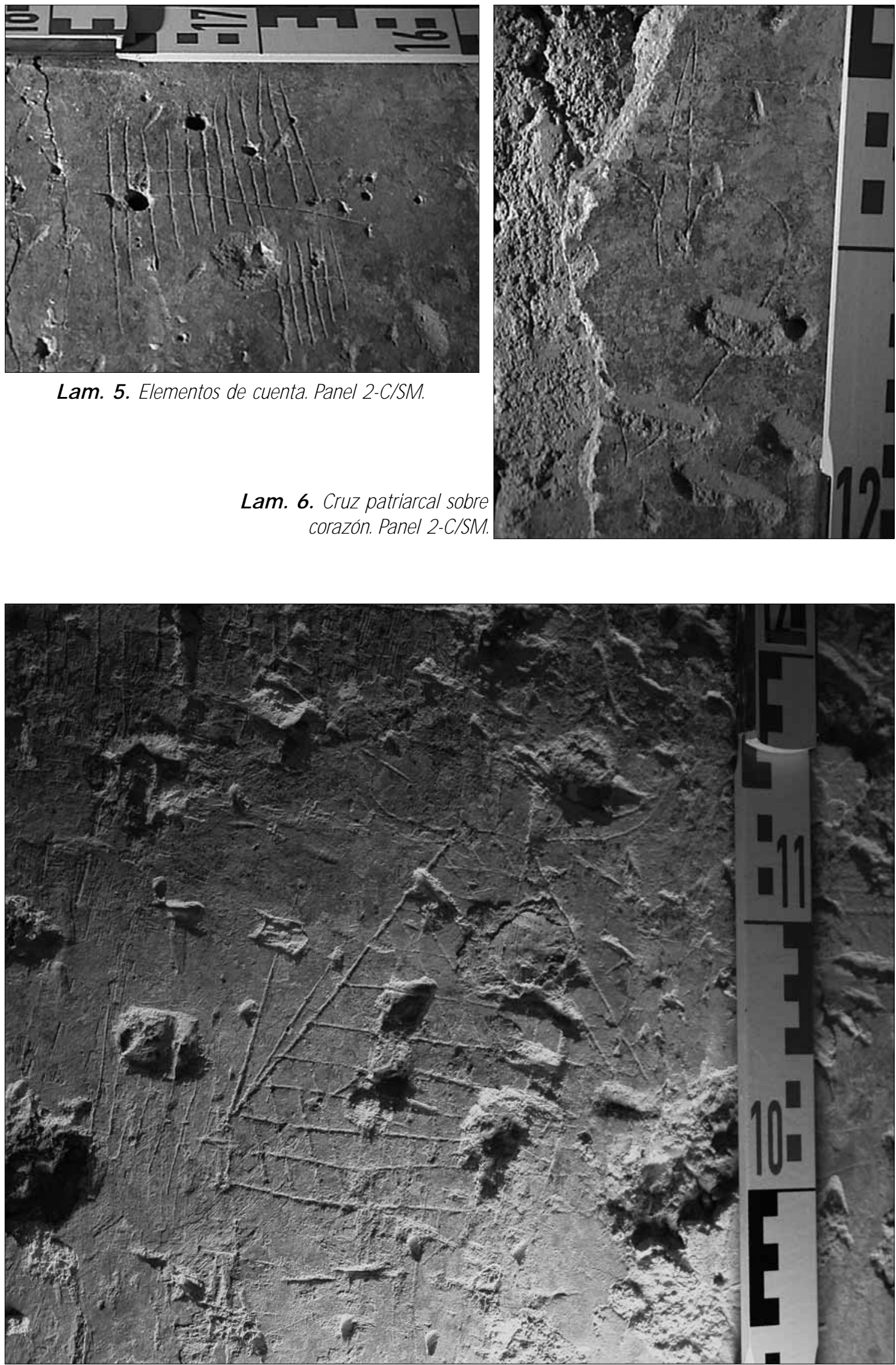

Lam. 7. Personaje con falda cuadriculada y brazos en cruz. Panel 3-C/SM . 


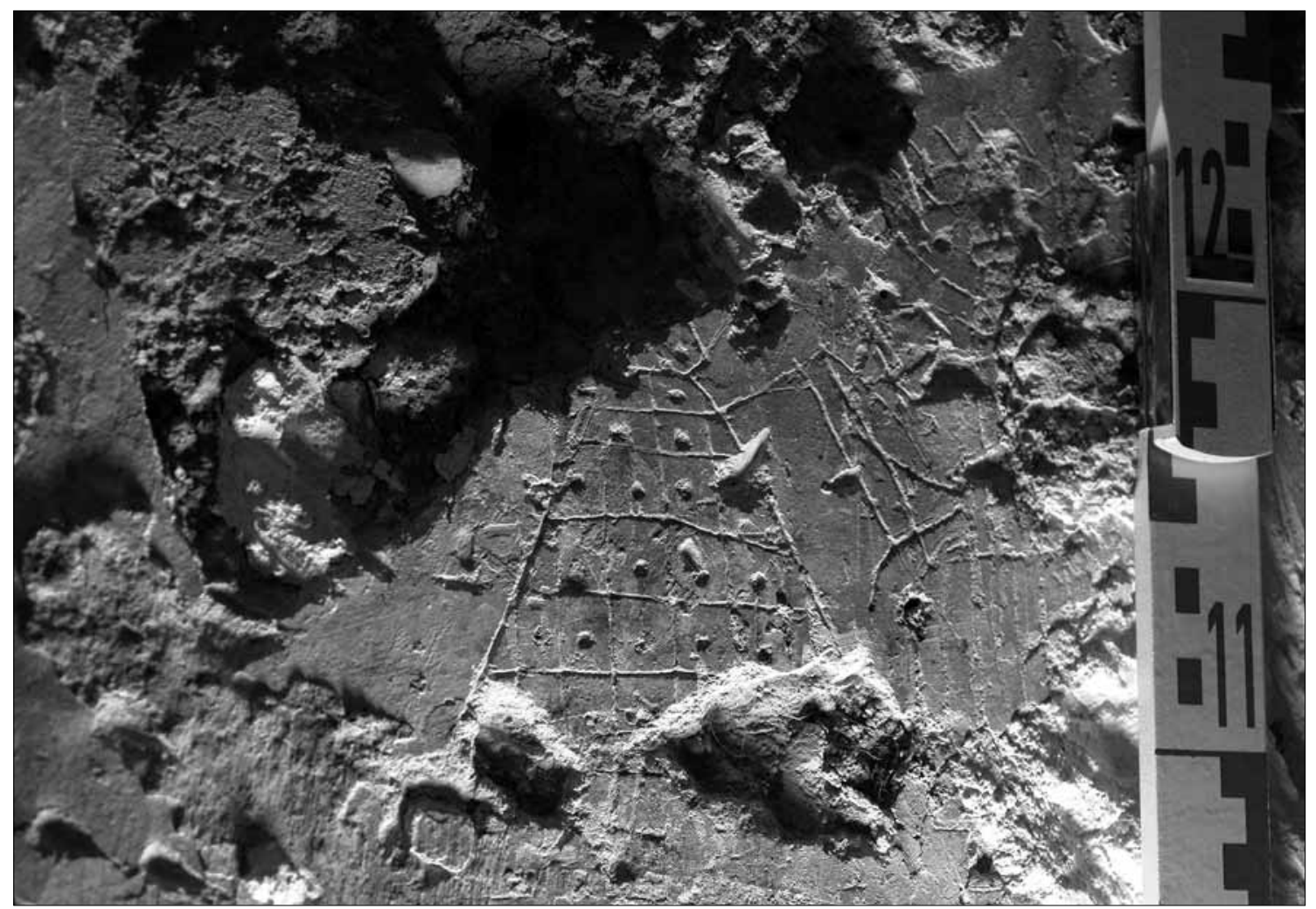

Lam. 8. Personaje con falda cuadriculada y rostro grotesco. Panel 3-C/SM .

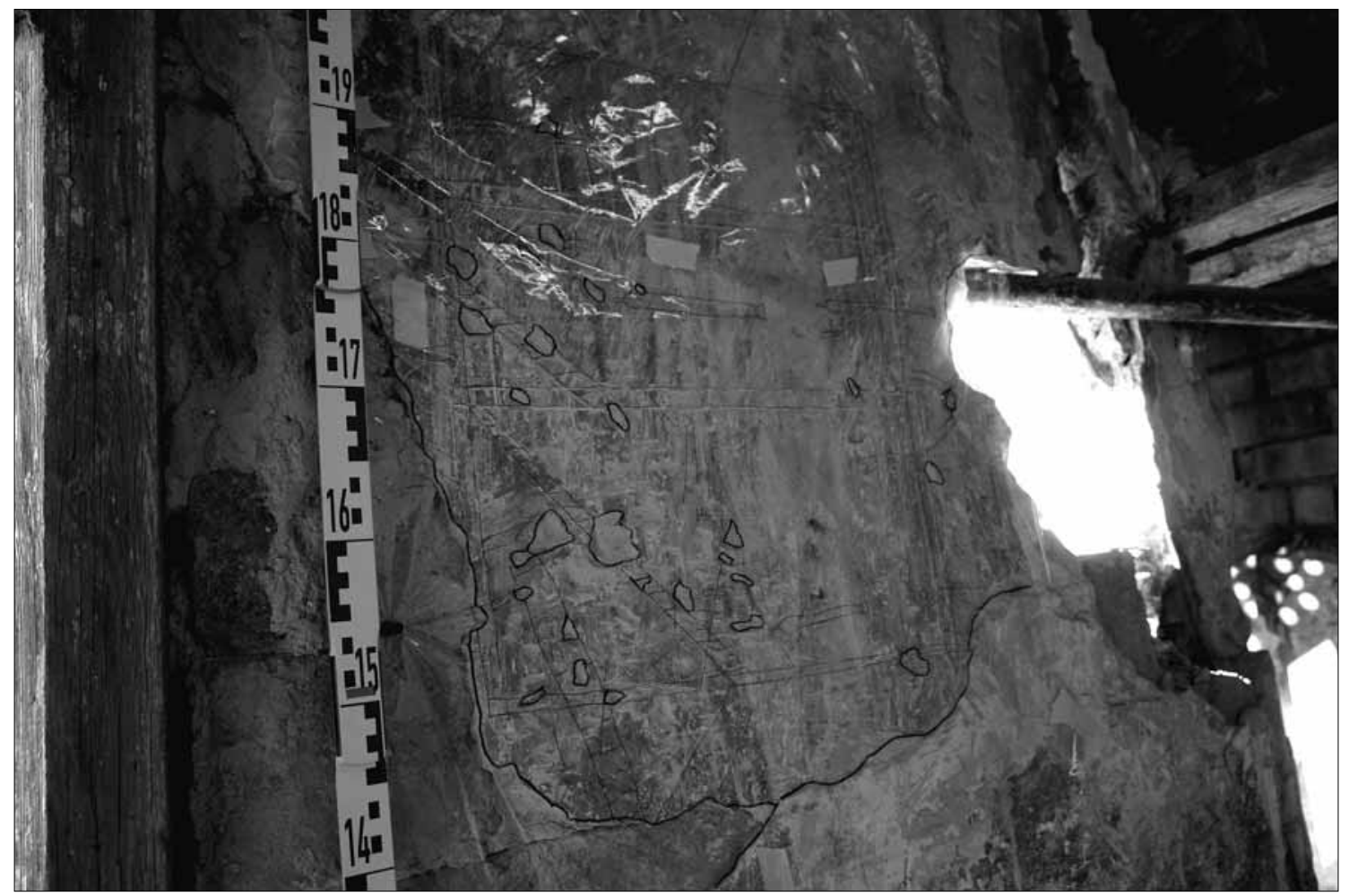

Lam. 9. Vista del Panel 4-C/SM durante el proceso de calco. 


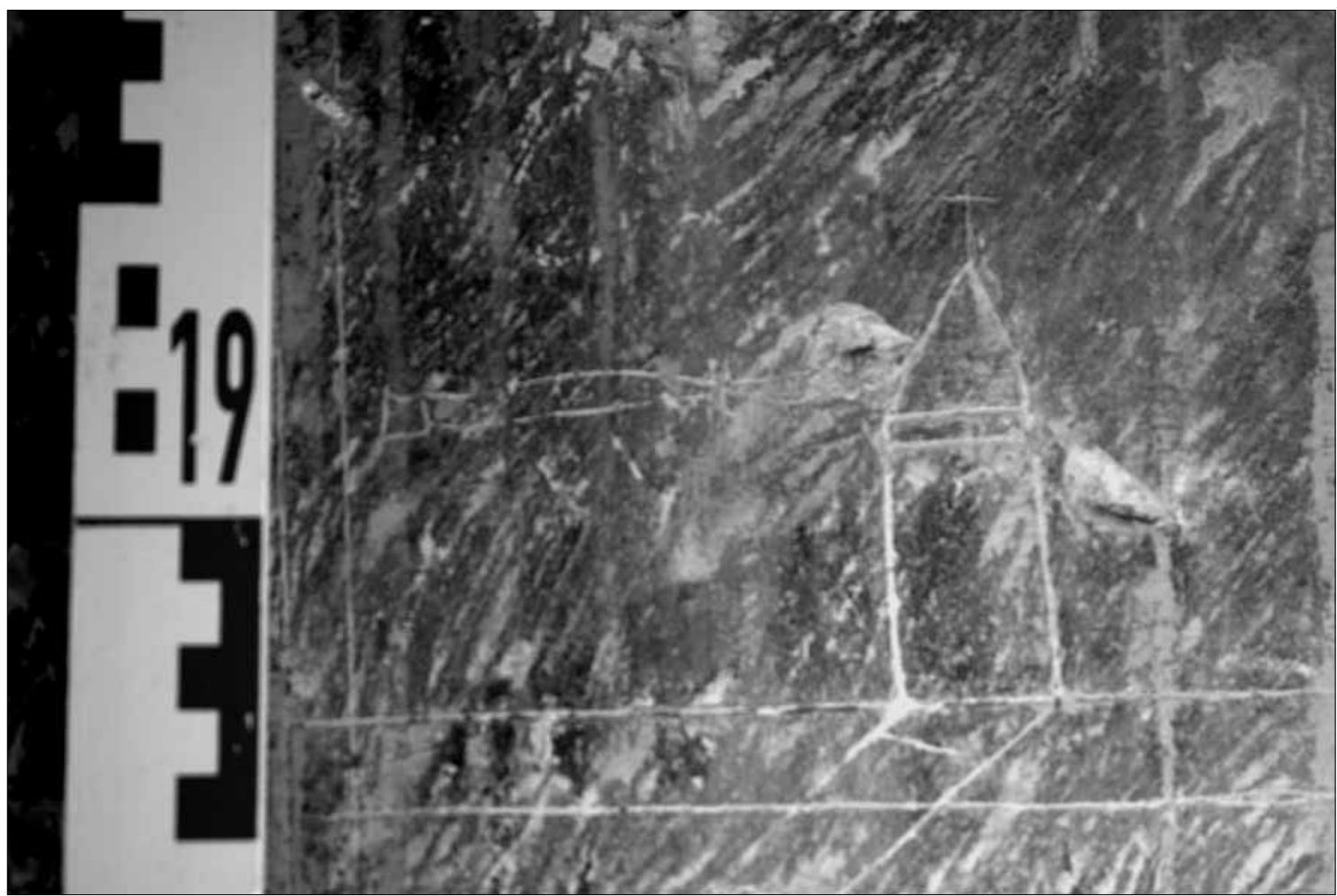

Lam. 10. Pieza de artillería y arco con cruz. Panel 4-C/SM.

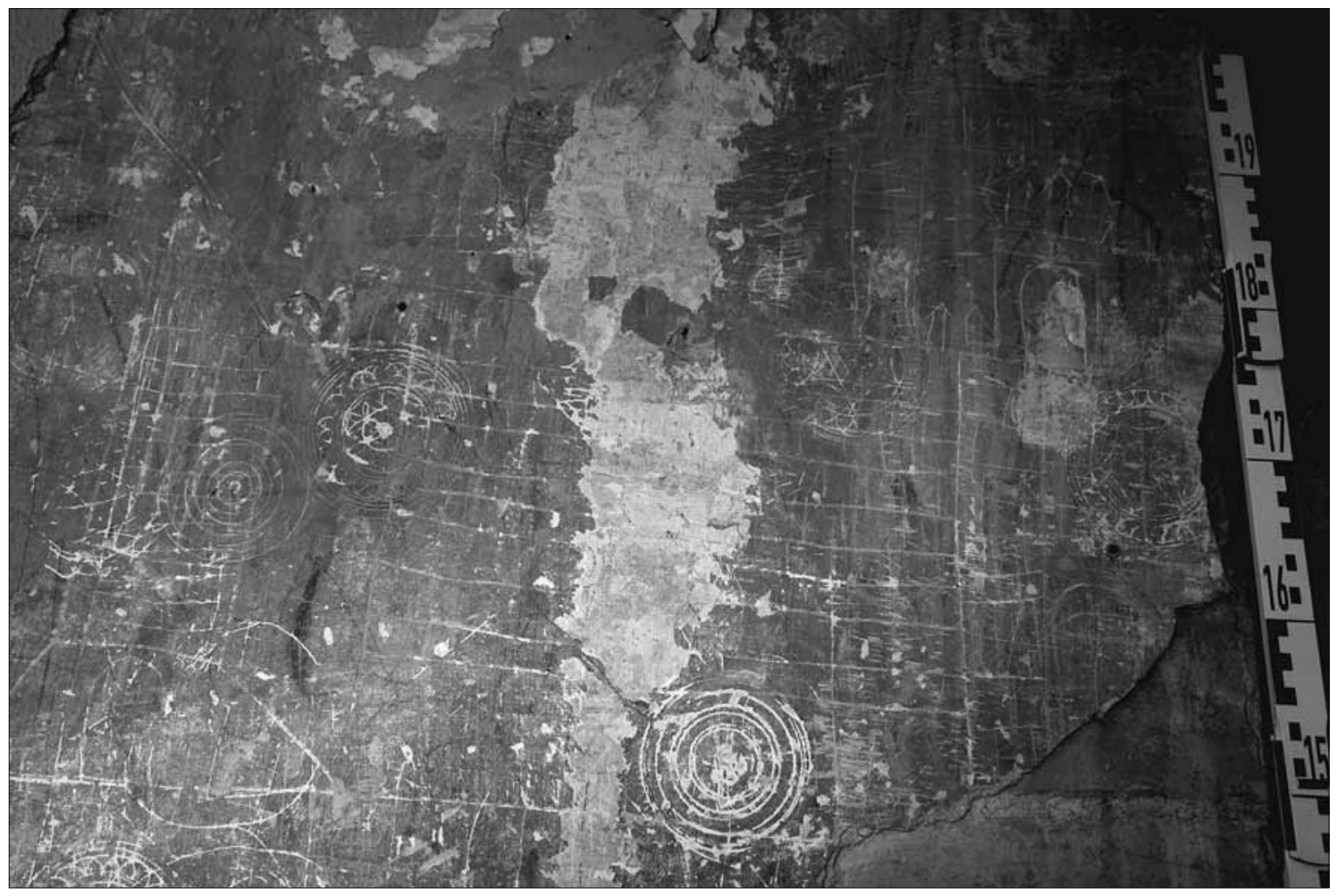

Lam. 11. Vista del Panel 5-C/SM durante el proceso de limpieza. 


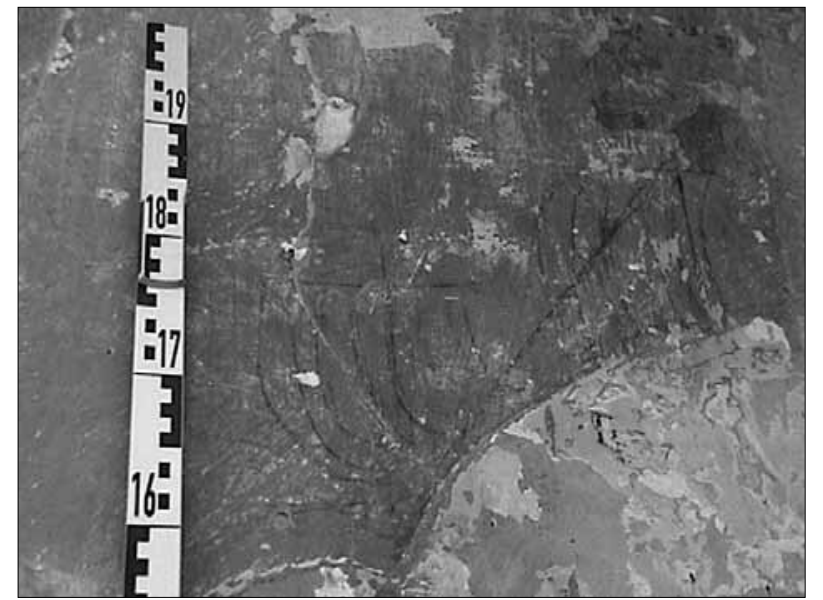

Lam. 12. Barco. Panel 5-C/SM.

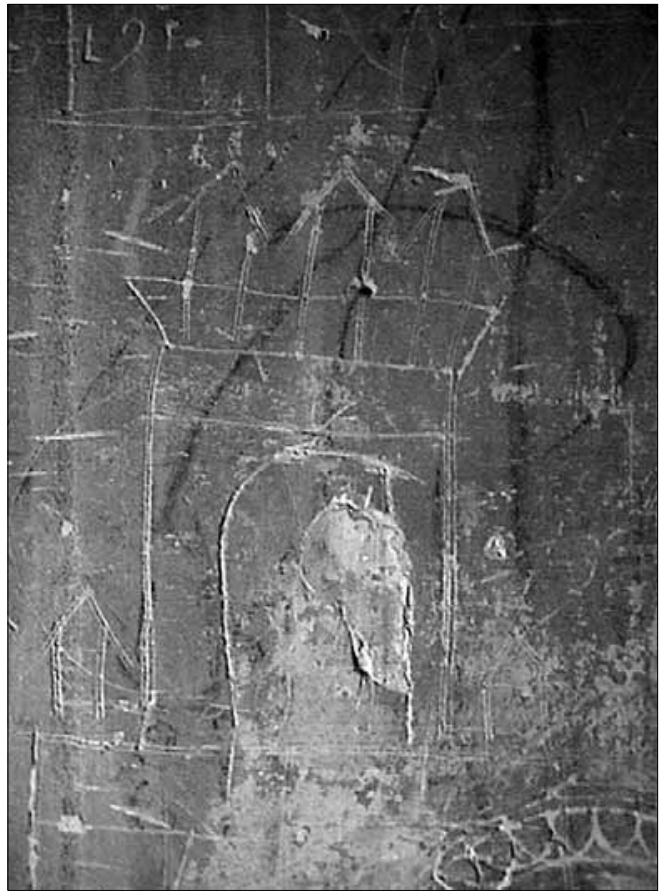

Lam. 14. Detalle de la torre caballera del gran castillo. Panel 5-C/SM.

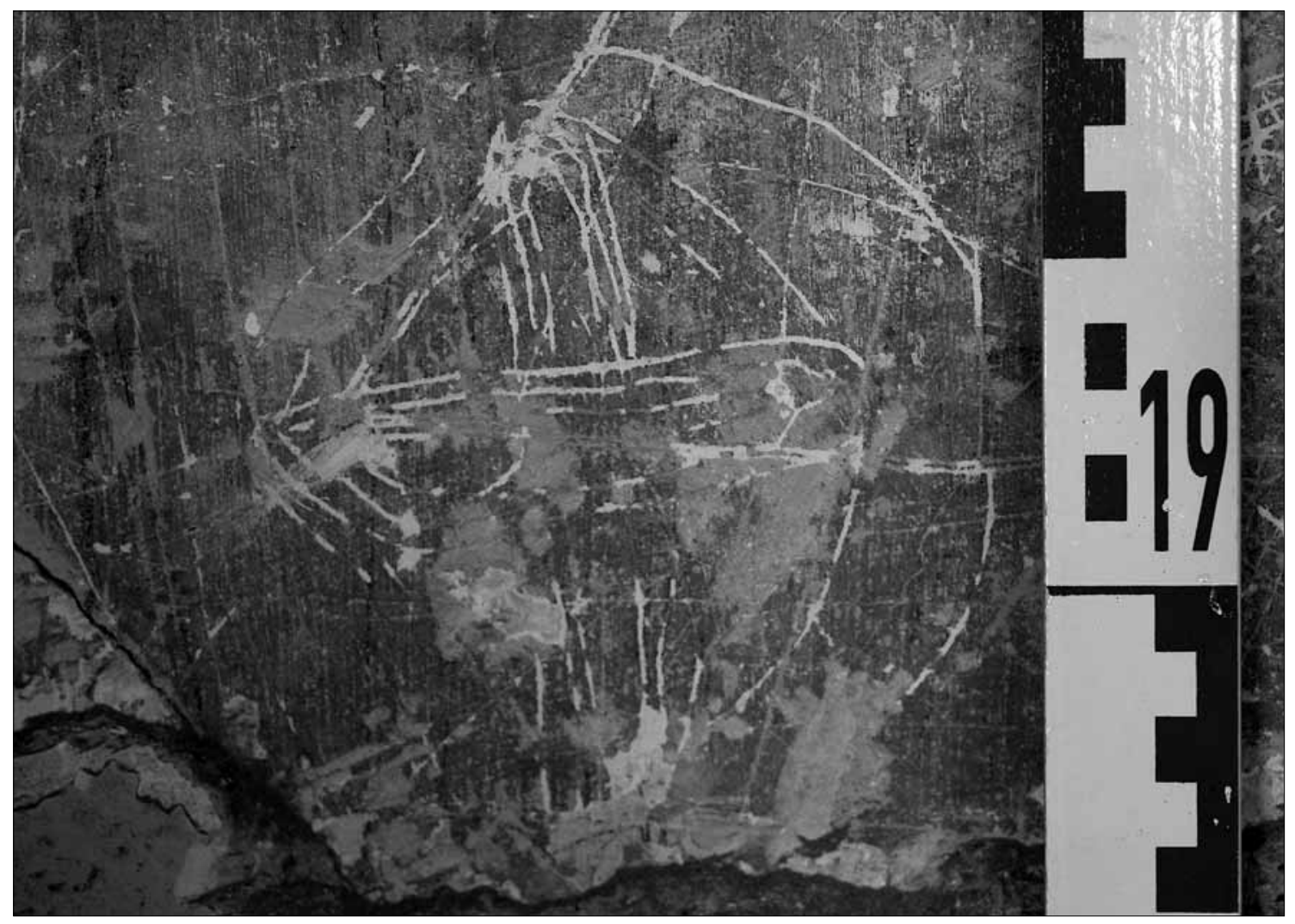

Lam. 13. Cruz contorneada. Panel 5-C/SM . 


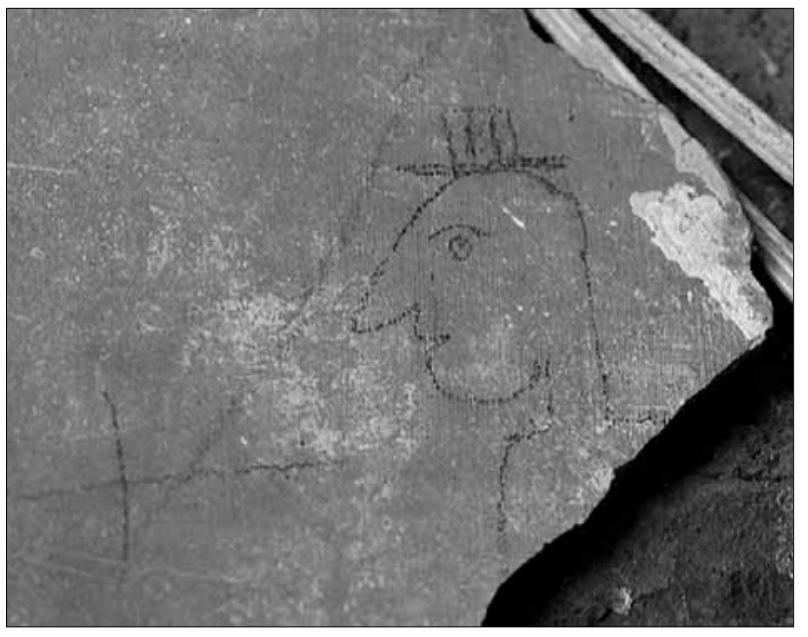

Lam. 15. Personaje con sombrero

a carboncillo. Panel 5-C/SM.

Lam. 16. Inscripción árabe. Panel 5-C/SM .
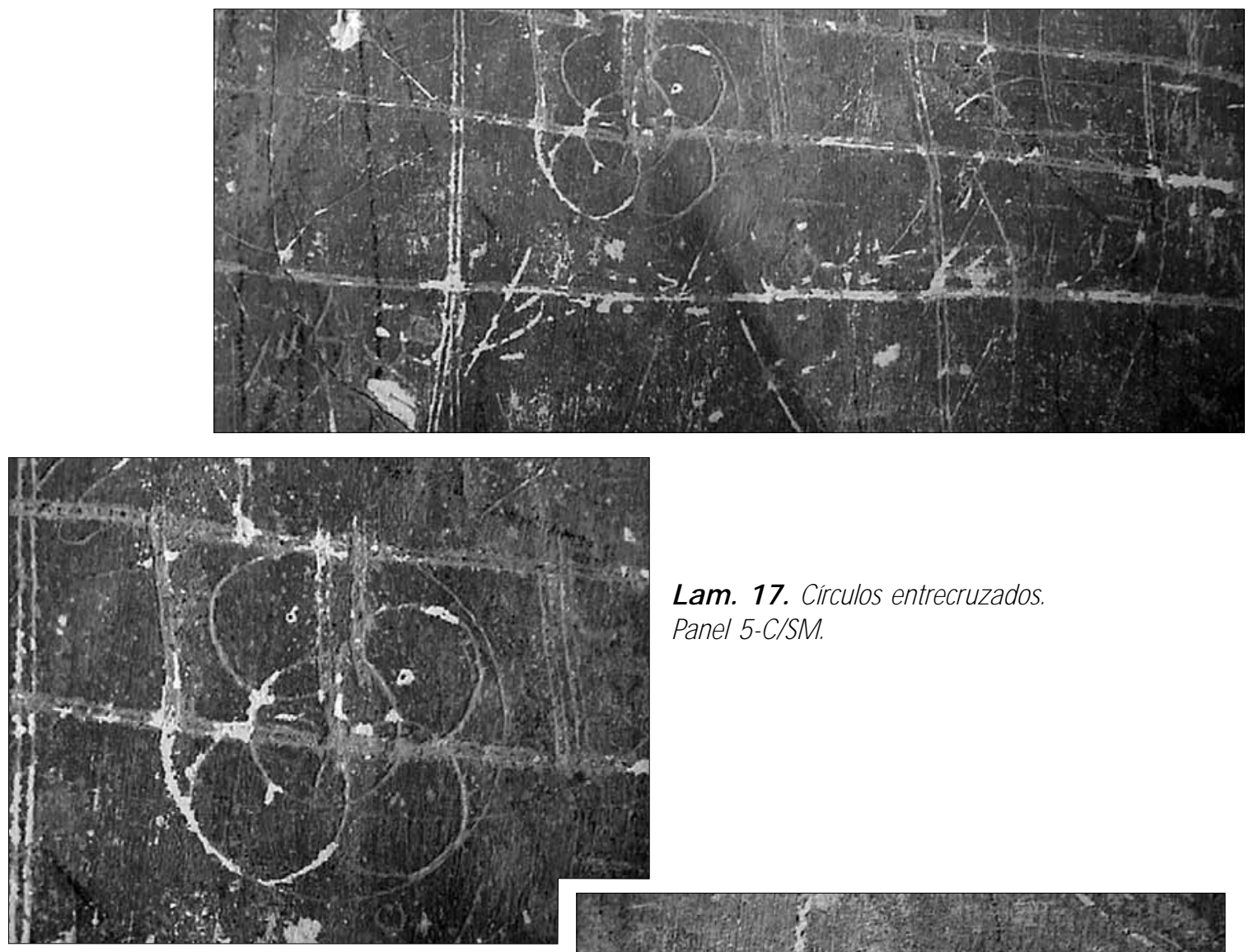

Lam. 17. Círculos entrecruzados.

Panel 5-C/SM.

Lam. 18. Roseta hexapétala. Panel 5-C/SM.

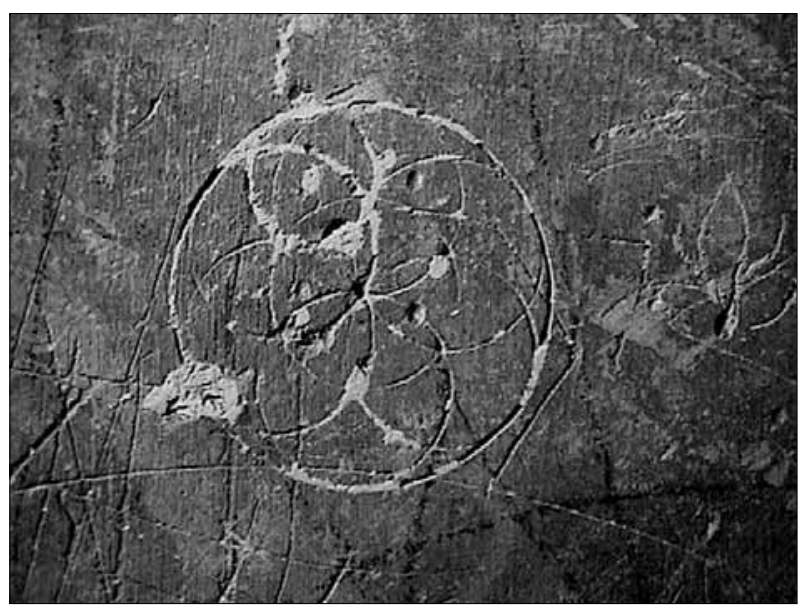




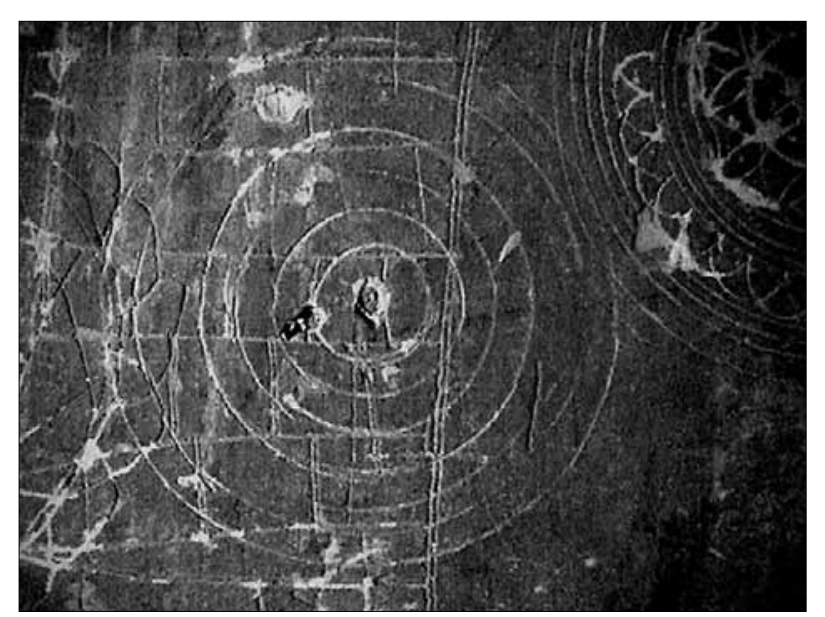

Lam. 19. Círculos concéntricos.

Panel 5-C/SM.

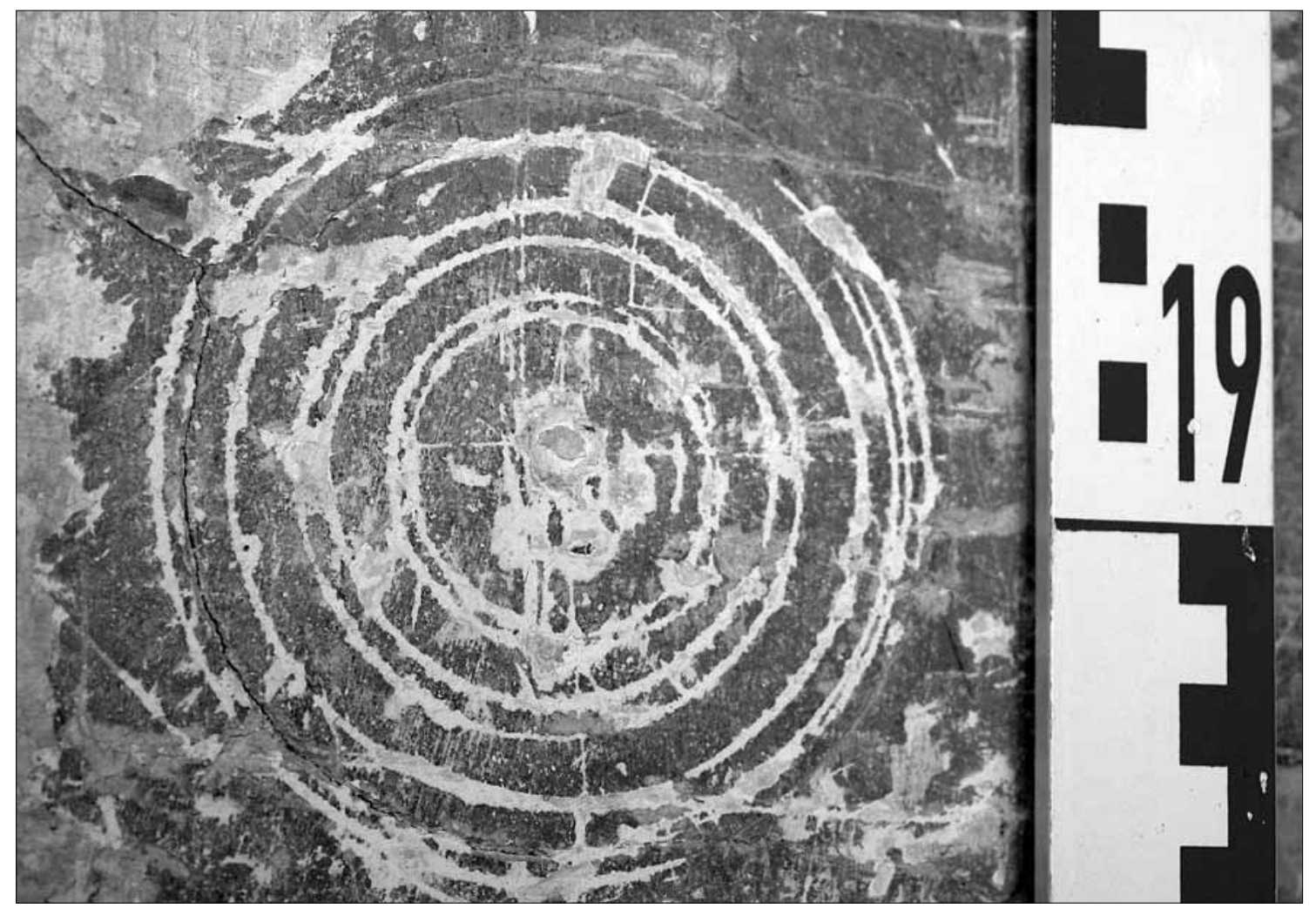

Lam. 20. Círculos concéntricos. Panel 5-C/SM.

Lam. 21. Estrella de seis puntas.

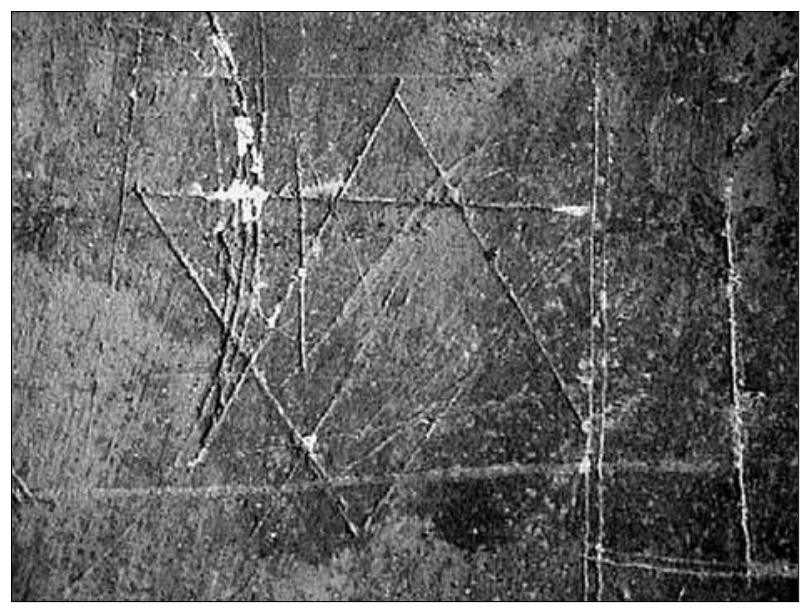

Panel 5-C/SM 


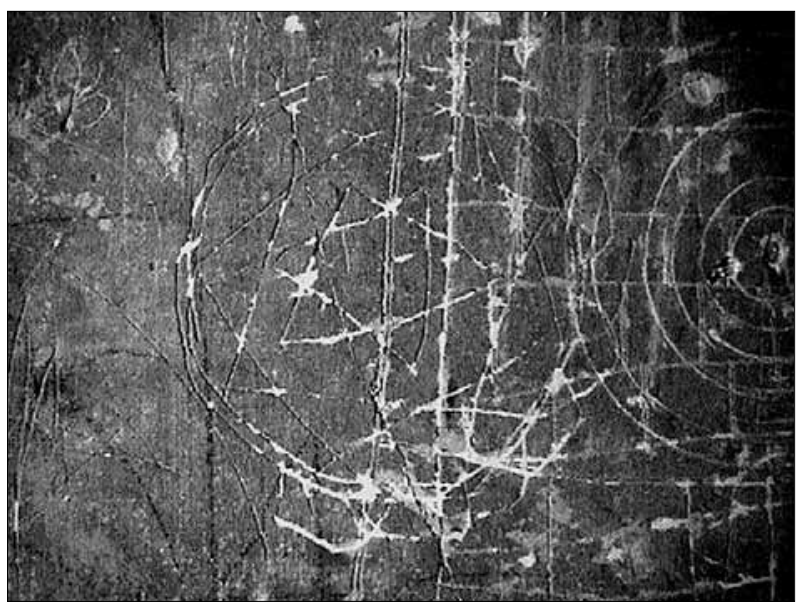

Lam. 22. Estrella de seis puntas dentro de otra de ocho. Panel 5-C/SM.

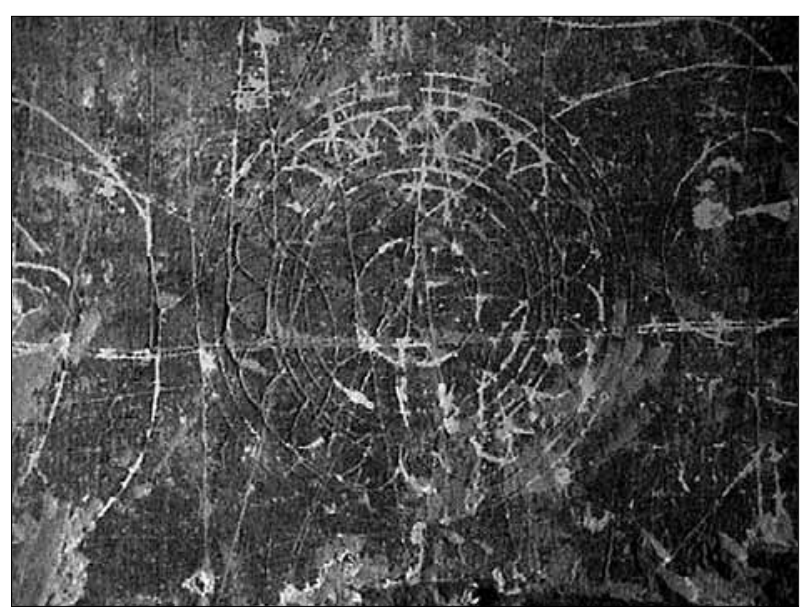

Lam. 23. Círculos concéntricos con arcos entrecruzados. Panel 5-C/SM.

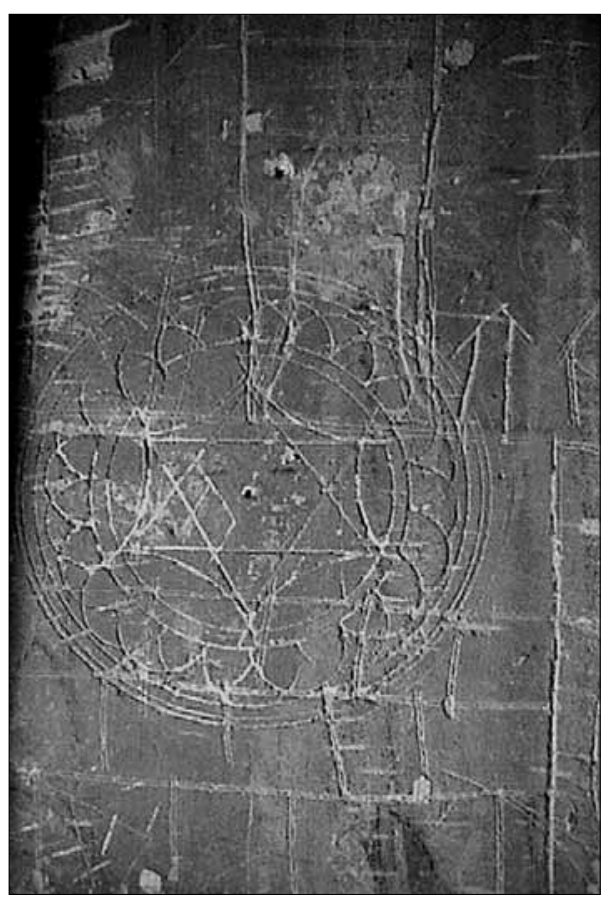

Lam. 24. Estrella de seis puntas inscrita en círculos concéntricos. Panel 5-C/SM.

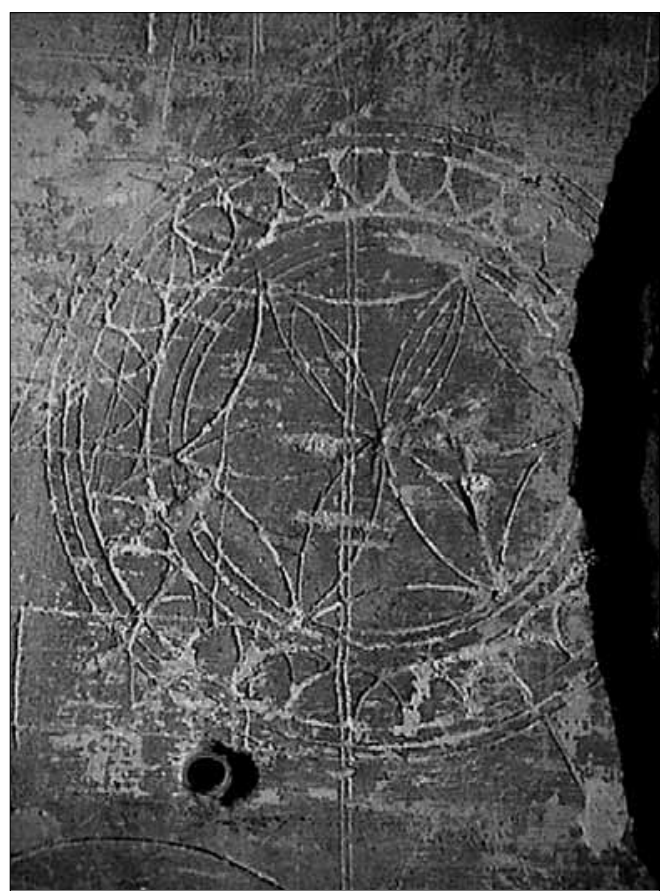

Lam. 25. Roseta hexapétala inscrita en círculos concéntricos. Panel 5-C/SM. 


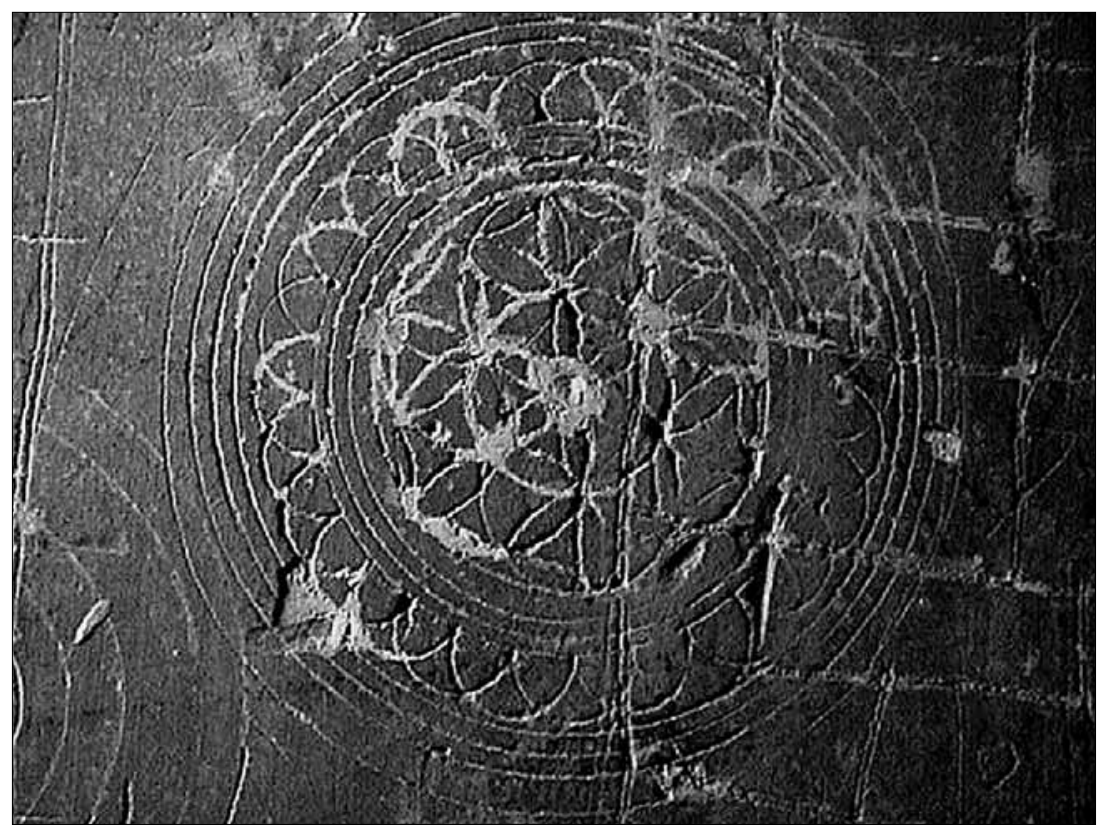

Lam. 26. Siete rosetas hexapétalas inscritas en círculos concéntricos. Panel 5-C/SM.

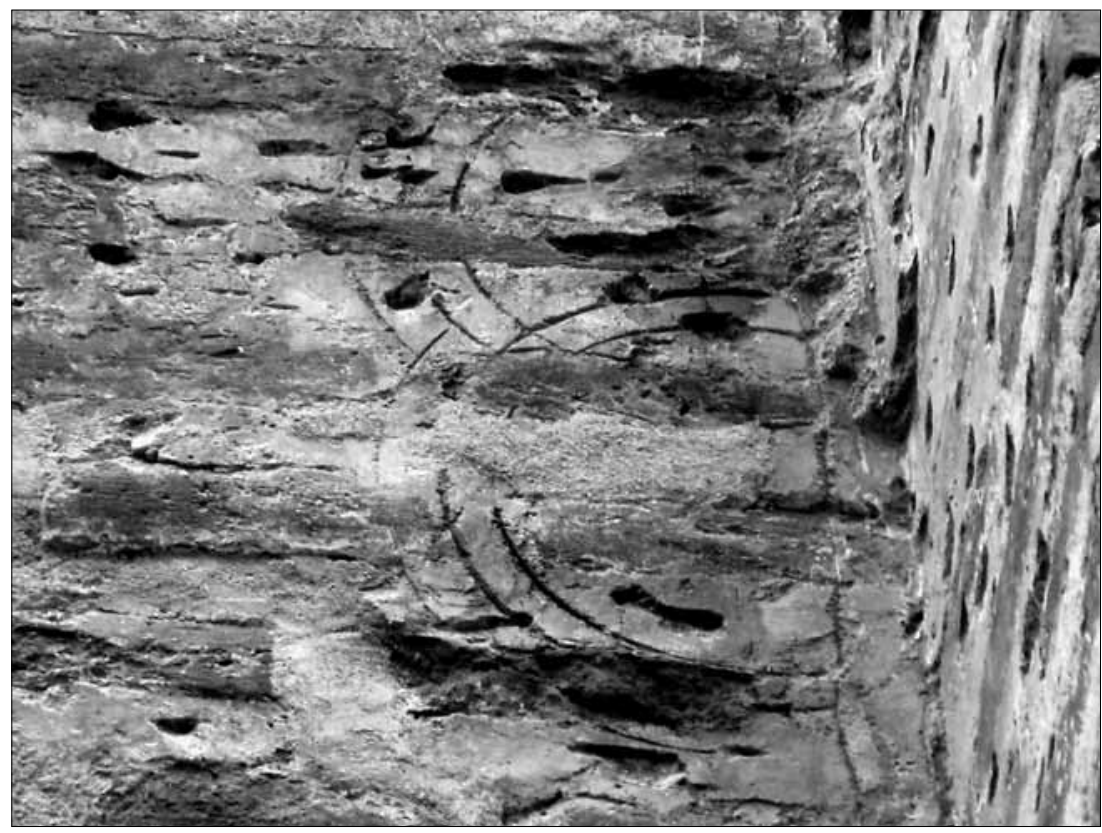

Lam. 27. Arcos entrecruzados incisos en el Corral del Carbón (Granada). 